\title{
Sporcularda Bağlanma Stillerinin Duyguları Düzenleme Becerileri ve Bilişsel Duygu Düzenleme Stratejilerini Belirlemedeki Rolünün İncelenmesi
}

\author{
Çiğdem ÖNER ${ }^{1 * \mathbb{D}}$, F. Hülya AŞÇI ${ }^{1}$ (D) \\ ${ }^{1}$ İstanbul Gelişim Üniversitesi, Beden Eğitimi ve Spor Yüksekokulu, İstanbul. \\ ${ }^{1}$ Marmara Üniversitesi, Spor Bilimleri Fakültesi, İstanbul.
}

Orijinal Makale

Gönderi Tarihi: 22.09.2020
Kabul Tarihi: 20.11.2020
DOI: $10.25307 / j s s r .798619$

Online Yayın Tarihi: 31.12 .2020

\section{$\ddot{O} \mathbf{z}$}

Sporcuların bağlanma stillerinin duyguları düzenleme becerileri ve bilişsel duygu düzenleme stratejilerini belirlemedeki rolünün incelenmesinin amaçlandığı bu çalışma ilişkisel tarama modeline dayalı olarak yapılmıştır. Çalışmaya İ́stanbul İlinden 18-30 yaş arası 235'i erkek ve 125'i kadın toplam 360 lisanslı sporcu katılmıştır. Katılımcılara, İlişski Ölçekleri Anketi, Duyguları Düzenleme Becerileri Ölçeği, Bilişsel Duygu Düzenleme Ölçeği ve Kişisel Bilgi Formu uygulanmıştır. Veriler; betimsel istatistikler, bağımsız gruplar için t-testi, Pearson korelasyon analizlerinin yanı sıra hiyerarşik regresyon analizleri ile sınanmıştır. Sonuçlar, kadın sporcuların korkulu bağlanma puanlarının erkeklerin puanlarından, erkek sporcuların diğerlerini suçlama puanlarının ise kadınlardan anlamlı olarak daha yüksek olduğunu, bireysel performans sporcularının kayıtsız bağlanma, değişimleme, pozitif tekrar odaklanma, plana tekrar odaklanma, pozitif tekrar gözden geçirme ve bakış açısına yerleştirmek puanlarının takım performansı sporcularına göre daha yüksek olduğunu, takım performans sporcularının yıkım puanlarının bireysel sporculardan daha yüksek bulunduğunu göstermiştir. Bağlanma stillerinin duyguları düzenleme becerileri ile bilişsel duygu düzenleme stratejilerini yordayıcılığını ortaya koymak üzere uygulanan hiyerarşik regresyon analizleri sonucunda; bağlanma stillerinin kabul ve tolerans dışında sırasıyla farkındalık, beden duyumları, netlik, anlama, yüzleşmeye hazırlanma, öz-destek ve değişimleme olmak üzere tüm diğer duygu düzenleme becerilerinin anlamlı belirleyicisi olduğu tespit edilmiştir. Sonuçlar ayrıca, bağlanma stillerinin kendini suçlama, kabul etme, düşünceye odaklanma, pozitif tekrar odaklanma, plana tekrar odaklanma, pozitif yeniden gözden geçirme, bakış açısına yerleştirmek, yıkım ve diğerlerini suçlama olmak üzere tüm bilişsel duygu düzenleme stratejilerinin anlamlı belirleyicisi olduğunu göstermiştir. Bulgulara göre; bağlanma stillerinin sporcuların duygu düzenleme becerileri ile bilişsel duygu düzenleme stratejilerini belirlemelerinde etken olduğu söylenebilir. Anahtar Kelimeler: Bağlanma Stilleri, Duygu Düzenleme Becerileri, Bilişsel Duygu Düzenleme, Spor Psikolojisi

\section{Investigation of the Role of Attachment Styles in Determining Emotion Regulation Skills and Cognitive Emotion Regulation Strategies}

\begin{abstract}
The study aimed to investigate the role of athletes' attachment styles in determining emotion regulation skills and cognitive emotion regulation strategies. 235 male and 125 female, a total of 360 athletes aged between 18-30 years, participated in the study from Istanbul Province. The participants completed The Relationship Scales Questionnaire, Emotion Regulation Skills Questionnaire, Cognitive Emotion Regulation Questionnaire, and Personal Information Form. The data were analyzed with descriptive statistics, independent t-test, Pearson correlation analysis, and hierarchical regression analysis. The results showed that female athletes' fearful attachment scores were significantly higher than men's, and male athletes' blaming others scores were significantly higher than women's. Individual performance athletes had higher scores than team performance athletes in dismissing attachment, modification, positive refocusing, refocus on planning, positive reappraisal and putting into perspective. Besides, the team performance sport athletes had higher scores than individual's in catastrophizing. As a result of the hierarchical regression analysis applied to reveal the predictive effect of attachment styles on emotion regulation skills and cognitive emotion regulation strategies; apart from acceptance and resilience, attachment styles are significant determinants of all other emotion regulation skills, including awareness, sensation, clarity, understanding, readiness to confront, selfsupport, and modification, respectively. The results also showed that attachment styles were significant determinants of all cognitive emotion regulation strategies, including self-blame, acceptance, rumination or focus on thought, positive refocusing, refocus on planning, positive reappraisal, putting into perspective, catastrophizing, and blaming others. It can be concluded that attachment styles are effective in determining athletes' emotional regulation skills and cognitive emotion regulation strategies.
\end{abstract}

Keywords: Attachment Styles, Emotion Regulation Skills, Cognitive Emotion Regulation, Sport Psychology

\footnotetext{
* Sorumlu yazar: Dr.Öğr.Üyesi Çiğdem ÖNER, E-posta: esenlik@ cigdemoner.com.tr
} 


\section{GíRiş}

Sporda duyguları düzenleme, sportif performansın sergilenmesi, yarışma öncesi ve sonrası süreçler (Lane, Beedie, Jones, Uphill ve Devonport, 2012) ile sporcunun genel yaşamı ve iyilik hali (Lane, Beedie, Devonport ve Stanley, 2011) üzerinde etkili olmaktadır. Tanıma, anlama, tepki verme ve ifade aşamalarını içeren duygu düzenleme (Cirhinlioğlu, 2018), sporcunun; sağlığı geliştirme ve sağlık açısından riskli davranışları (Bekaroğlu ve Bozo, 2017) farklı bir söylemle sürdürülebilir sağlıklı yaşam davranışları, kişilerarası etkileşimi ve takım çalışmasına yatkınlığı (Tamminen ve Crocker, 2013; Campo vd., 2019), yaşam boyu öğrenme eğilimi (Consedine, 2011), özsaygısı (Tamminen ve Crocker, 2013; Garnefski ve Kraaij, 2007) ve değerleri (Kavussanu, 2008; Shields ve Bredemeier, 2007) açısından da önemlidir.

Gratz ve Roemer (2004), duygu düzenleme becerisini duyguların anlamını, tanınmasını, kabulünü, olumsuz bir duygu yaşanması halinde söz konusu duygunun denetlebilmesini, amaca yönelik davranışları sürdürme erkini ve ek olarak koşullara uygun duygu düzenleme stratejisini kullanmayı kapsayan bir yapı olarak değerlendirmektedir. Farklı bakış açısıyla, duygu düzenleme duygusal tepkileri izleme, değerlendirme ve bu içerikleri değiştirme sorumluluğunu taşıyan içsel ve dışsal süreçleri kapsamaktadır. Dışsal duygu düzenleme, kişinin bilincini, gayretini, ayırt ediciliğini ve gözlemlemesini gerekli kılmaktadır. İçsel duygu düzenleme ise kendiliğinden beliren, otomatik görünüm alan, farkındalık gerektirmeyen bir süreç olmaktadır. Duyguların, içsel ve dışsal ipuçlarının değerlendirilmesiyle oluştuğu esas alındığında, açığa çıkan duyguların belli bazı değerlendirmelerden geçerek farklı fiziksel, davranışsal ve deneyimsel yaşantılar sonucunda görüldüğ̈̈; bu değerlendirmeler esnasında duygu düzenleme yönelimi ile duygu ifadesinin son halini yarattığı, bu deneyimler sırasında duygu düzenlemenin çeşitli biçimlerde ortaya çıkabildiği izlenmektedir (Gross, 2014).

Duygu düzenlemenin önemli biçimlerinden biri de bilişsel duygu düzenlemedir. Bilişsel duygu düzenleme, sıkıntıya yol açan sorun ve duyguların üstesinden gelmenin "ruhsal yolu" olarak tanıtılmakta, alanyazında bilişsel baş etme ile eş anlamlı kullanılmaktadır (Garnefski, Kraaij ve Spinhoven, 2001). Bilişsel duygu düzenleme; uyumlu bilişsel başa çıkma ve uyumsuz bilişsel başa çıkma olarak iki ana başlıkta sınıflandırılan dokuz farklı stratejiyi içermektedir (Garnefski ve Kraaij, 2006, Garnefski ve Kraaij, 2007). Kendini suçlama, diğerlerini suçlama, düşünceye odaklanma ve yıkım uyumsuz başa çıkma stratejileri, kabul etme, plana tekrar odaklanma, pozitif tekrar odaklanma, pozitif tekrar gözden geçirme ve bakış açısına yerleştirme uyumlu başa çıkma stratejileri olarak değerlendirilmektedir (Garnefski vd., 2001). Uyumlu başa çıkma stratejileri iyimserlik, benlik saygısı (Garnefski vd., 2002; Garnefski ve Kraaij, 2007) ve psikolojik iyi oluşla (Schroevers, Kraaij ve Garnefski, 2007), uyumsuz başa çıkma stratejileri ise; duygusal sorunlarla (Garnefski ve Kraaij, 2006), psikopatolojiyle (Garnefski vd., 2002; Kraaij, Garnefski ve Vlietstra, 2008) ve depresyonla (Çalışır, 2009; Andrés, Richaud de Minzi, Castañeiras, Canet-Juric ve Rodríguez-Carvajal, 2016) ilişkilendirilmiştir.

Duyguları düzenleme sürecinin farklı faktörlerden etkilenmekte olduğu bilinmektedir. $\mathrm{Bu}$ etmenlerden biri de bağlanma stilleridir. Bağlanma (Bowlby, 1983) kişilerin önemli gördükleri diğerleri ile güçlü duygusal bağlar geliştirerek yakın duygusal ilişkiler kurma gereksiniminin karşılanmasıdır. Sümer ve Güngör (1999) bağlanma sisteminin, çoğunlukla anne olmak üzere bakım verenlerle fiziksel yakınlığı güçlü tutarak, hem çevreden kaynaklanabilecek olası risklerden korunmayı hem de çevreyi keşif bağlamında uygun koşulları sağladığını ve yakınlığın korunumu ile çocuğa güven içinde gelişeceği alan yarattığını vurgulamaktadır. 
Hazan ve Shaver'a (1994) göre, bağlanma sistemi dört farklı davranış örüntüsüne dayandırılarak açıklanmaktadır; yakınlığı arama ve koruma, ayrılığı reddetme, keşfetme faaliyetleri için bakım vereni 'güvenli üs' olarak görme, destek ve güvenlik amacıyla bakım vereni 'sağlam bir sığınak' olarak kullanma. Main, Kaplan ve Cassidy (1985), yetişkinlerin çocukluk evrelerine ilişkin değerlendirmelerinin mevcut deneyimsel süreçteki işlevselliklerine tesir edebileceği görüşünden hareketle, güvenli-otonom, kayıtsı, saplantılı ve çözümlenmemiş-dezorganize kategorilerinden oluşan dörtlü yetişkin bağlanma modelini öne atmışlardır (Çalışır, 2009). Bartholomew ve Horowitz (1991) ise dört kategori modeli isimli çalışmalarında, yetişkin bağlanma tarzlarını olumlu/olumsuz kutuplarda değerlendirilen zihinsel modellerin kesiştiği noktada tanımlayarak, modeli; güvenli, korkulu, saplantılı ve kayıtsız bağlanma olarak anılan dört örüntü etrafında şekillendirmişlerdir.

Egzersiz ve spor psikolojisi alan yazını incelendiğinde, sporcular üzerinde yapılan çalışmalarda duygu düzenleme ile atletik kimlik (Costa vd., 2020), psikolojik dayanıklılık (Şahin ve Güçlü, 2018), fiziksel toparlanma (Molina, Oriol ve Mendoza, 2018), bilinçli farkındalık ve ruminasyon (Josepfsson vd., 2017), sosyal kaygı ve öfke (Öpöz, 2017), sportif performans (Wagstaff, 2014), mükemmeliyetçilik (Hill ve Davis, 2014) ile başa çıkma ve sosyal destek (Tamminen ve Gaudreau, 2014) ilişsisinin araştırıldığı görülmektedir.

Elibol ve Sevi Tok (2019) tarafından da vurgulandığı gibi duygu düzenlemeye ilişkin çalışmalar dayanağını, duygu (Frijda, 1986), bağlanma (Bowlby, 1983), stres ve başa çıkma (Lazarus, 1966) ve savunma mekanizmalarına (Freud, 2018) ilişkin teorilerden almaktadır. Nitekim, Bowlby (1983) bağlanma kuramının temelinde yer alan içsel çalışan modellerin asıl hedefinin duygulanım düzenlenmesi olduğunu öne sürmektedir. Çalışır'ın (2009) da ifade ettiği üzere bağlanma ve duygu düzenleme ilişkisini konu edinen yetişkin alanyazınındaki pek çok görgül çalıșma, içsel modeller ile bilișsel temsillerin duygusal tepkileri nasıl etkilediği sorusuna yanıt aramaktadır. Yapılan bazı araştırma sonuçları, farklı bağlanma biçimlerinin farklı duygusal tepkisellikleri ortaya çıkardığını, ortaya çıkan duygular doğrultusunda bireylerin duygu düzenleme becerileri ile stratejilerinin birbirlerinden farklılaştığını teyit etmektedir (Bartholomew ve Horowitz, 1991; Gross, 2014). Aktarllanlardan hareketle, bu farklılaşmanın sporcular özelinde nasıl gerçekleştiğinin ortaya konması psikolojik performansın korunumu ve sürdürülebilirliği bağlamında bir gereklilik olarak değerlendirilmiştir. Sporcu açısından duygu düzenleme, doruk performansa ulaşmasına destek veren ya da engel oluşturan duygusal tepkilerin kontrolü, izlenmesi, değerlendirilmesi ve değiştirilmesini içeren bir süreci ifade etmektedir. Hedefi gerçekleştirme, performansı geliştirme, sağlığ koruma ve sürdürme erki bu sürecin öne çıkan diğer bileşenleri olarak görülmektedir. Sporcu gerek müsabaka öncesi ve sonrası gerekse müsabaka sırasında duygu düzenleme stratejilerini kullanmakta, duygu düzenlemeye yönelik davranış kalıpları ile hareket etmektedir. Bu bağlamda, duygu düzenleme beceri ve bilişsel duygu düzenleme stratejilerini işe koşmanın yönetilebilir seviyede olması üst düzeyde önemli bulunmaktadır. Yapılan alanyazın taramasında, sporcuların bağlanma stillerinin duygu düzenleme becerileri ve bilişsel duygu düzenleme stratejileri ile birlikte ele alındığı bir çalışmaya rastlanmamış olması bu araştırmaya yön vermiştir. Bu bilgiler 1şı̆̆ında, sporcuların bağlanma stilleri ile duygu düzenleme becerileri ve duygu düzenleme stratejileri arasındaki ilişkilerin ortaya konmasının, sporda psikolojik performans danışmanlığı yapan uzmanlara ve psikolojik beceri antrenman içeriklerinin tasarlanma ve yapılandırılma süreçlerine katkı sağlayacağı öngörülmektedir. Bu öngörüden yola çıkarak, çalışmada sporcuların bağlanma stillerinin duyguları düzenleme 
becerileri ile bilişsel duygu düzenleme stratejileri üzerindeki yordayıcı rolünün belirlenmesi amaç edinilmiştir. Sporcuların cinsiyet, spor türü ve spor deneyimlerinin bağlanma stilleri, duygu düzenleme becerileri ve bilişsel duygu düzenleme değişkenleri açısından anlamlı şekilde farklılaşıp farklılaşmadığının ortaya konulması, çalışmanın bir diğer amacını oluşturmuştur.

\section{YÖNTEM}

Araştırma Modeli: Bu çalışma, nicel araştırma desenlerinden ilişkisel tarama modeline uygun biçimde tasarlanmıştır. İlişkisel tarama modelleri, Karasar (2020) tarafından bildirildiğine göre, iki veya daha fazla sayıda değişken arasında birlikte değişim olup olmadığını, olması halinde söz konusu değişimin derecesini ortaya koymayı önceliklendiren modellerdir.

Araştırma Grubu: Araştırmanın çalışma grubunu, İstanbul ilinde yaşamakta olan 18-30 yaş arası 235'i erkek (yaş ort. 22.58 \pm 2.98 , spor deneyim ort. $8.57 \pm 4.50$ yıl), 125'i kadın (yaş ort. $23.46 \pm 3.42$, spor deneyim ort. $8.70 \pm 4.39$ y1l) toplam 360 genç yetişkin lisanslı aktif performans sporcusu oluşturmaktadır. Olasılıksız örneklem yöntemlerinden uygun örnekleme metoduna dayandırılan çalışmada gönüllülük esası gözetilmiş, basketbol (36 erkek, 24 kadın), futbol (60 erkek), karate (31 erkek, 29 kadın), sualtı hokeyi (34 erkek, 26 kadın), tenis (33 erkek, 27 kadın) ve son olarak yüzme (41 erkek, 19 kadın) branşlarında performans sergileyen bireysel ve takım sporcuları çalışma kapsamına alınmıştır.

Veri Toplama Araçları: Araştırmanın verileri Kişisel Bilgi Formu, İlişki Ölçekleri Anketi, Duyguları Düzenleme Becerileri Ölçeği ve Bilişsel Duygu Düzenleme Ölçeği aracılığı ile toplanmıştır.

Kişisel Bilgi Formu: Araştırmacılar tarafından hazırlanan kişisel bilgi formunda; sporcuların cinsiyeti, spor branşı ve spor deneyimi (yıl) sorulmuştur.

İlişki Ölçekleri Anketi: Yetişkinlerin bağlanma stillerini ölçmek amacıyla Griffin ve Bartholomew'un (1994) geliştirdiği ölçeğin geçerlik, güvenirlik ve Türkçe uyarlama çalışmasını Sümer ve Güngör (1999) gerçekleştirmiştir. İlişki Ölçekleri Anketi 'İ̈A' “1: Hiç benim gibi değil ve 7: Tamamen benim gibi” arasında derecelenen 7'li likert tipindedir. Ölçek, güvenli, korkulu, saplantılı ve kayıtsız bağlanma olmak üzere 4 alt boyut ve 30 maddelidir. Alt boyutlardan alınan en yüksek puan sahip olunan bağlanma stilini yansıtmaktadır (Sümer ve Güngör, 1999). Bu çalışma grubunun güvenirlik analizlerine göre iç tutarlılık katsayıları; güvenli bağlanmada 0.81 , korkulu bağlanmada 0.70 , saplantılı bağlanmada 0.81 , kayıtsız bağlanmada 0.80 ' dir.

Duygu Düzenleme Becerileri Ölçeği: Berking ve Znoj'un (2008) geliştirdiği 5'li likert tipi ölçek, Vatan ve Oruçlular Kahya'nın (2018) geçerlik ve güvenirlik çalışması ile Türk diline uyarlanmıştır. Duyguları Düzenleme Becerileri Ölçeği 'DDBÖ’, “0: Neredeyse hiçbir zaman, 4: Neredeyse her zaman” aralığında derecelendirmeli 27 madde ve 9 alt boyut içermektedir. $\mathrm{Bu}$ boyutlar, sirasıyla farkındalık, beden duyumları, netlik, anlama, kabul, tolerans, yüzleşmeye hazırlanma, öz-destek ve değişimlemedir. Her biri 3 madde içeren alt boyutlar dışında ölçek toplam puan da vermekte, ters puanlanan madde bulunmamaktadır (Vatan ve Oruçlular Kahya, 2018). Bu araştırmanın çalışma grubu için DDBÖ güvenirlik katsayısı 0.91 hesaplanmış, alt ölçeklerin cronbach alfa değerlerinin 0.68 ile 0.89 arasında değişmekte olduğu bulunmuştur. 
Bilişsel Duygu Düzenleme Ölçeği: Ölçek, Garnefski, Kraaij ve Spinhoven (2001) tarafından geliştirilmiş, Onat ve Otrar'ın (2010) geçerlik ve güvenirlik çalışması ile Türk diline uyarlanmıştır. Bilişsel Duygu Düzenleme Ölçeği 'BDDÖ' "1: Hiçbir zaman, 5: Her zaman” arasında derecelendirilen 5'li likert tipinde, her biri 4 madde içeren 9 alt boyutta tasarlanmıştır. Kabul etme, pozitif tekrar odaklanma, plana tekrar odaklanma, pozitif yeniden gözden geçirme ve bakış açısına yerleştirmek alt boyutları uyumsal bilişsel duygu düzenleme stratejileri, kendini suçlama, düşünceye odaklanma, felaketleştirme ve başkalarını suçlama uyumsal olmayan bilişsel duygu düzenleme stratejileri olarak düşünülmüştür. Alınan yüksek puanlar ilişkili olan alt boyuta ait bilişsel duygu düzenleme stratejisinin daha çok kullanıldığına işaret etmektedir (Onat ve Otrar, 2010). Bu araştırmanın çalışma grubu için hesaplanan cronbach alfa değerleri 0.64 ile 0.85 aralı̆̆ındadır.

Araştırma Etiği: Bu çalışma, İstanbul Gelişim Üniversitesi Etik Kurul Başkanlığ 17.05.2019 tarih 2019-13-8 sayılı kararı ile alınan izine dayalı olarak yürütülmüştür.

Verilerin Analizi: İstatistiksel analizler öncesinde frekans analizi ile veri girişinin doğruluğu sınanmış, yanlış ya da eksik girilen madde olmadığı saptanmıştır. İzleyen aşamada, ölçeklerin toplam ve alt boyut puan kodlamaları yapılmış, tüm ölçek boyutları için toplam puanlar hesaplanmıştır. Ölçeklerin ham toplam puanları standart z puanlarına dönüştürülmüş, \pm 3 aralığ dışında kalan katılımcının olmadığı görülmüş, 360 kişiden toplanan verilerin tamamı analize alınmıştır. Hangi analizlerin kullanılacağının tespiti için verilerin normal dağılıma uygunluklarına bakılmış, alınan tüm alt ölçek puanlarının çarpıklık ve basıklık değerleri hesaplanmıştır. Liu, Marchewka, Lu ve Yu'ya (2005) göre, çarpıklık ve basıklık değerlerine ilişkin beklenen istatistik değer aralığ $\% 5$ güven aralığı esas alındığında $\pm 2.58, \% 1$ güven aralığında ise \pm 1.96 olmalıdır. Bu çalışmada, çarpıklık basıklık değerlerinin \pm 2 aralığında bulunması sonucunda analizlerde parametrik testlerin kullanılmasına karar verilmiştir. $\mathrm{Bu}$ nedenle, cinsiyet, spor türü (bireysel/takım sporları) ve spor deneyimine göre bilişsel duygu düzenleme becerileri ve bilişsel duygu düzenleme stratejileri arasındaki farkın analizinde bağımsız gruplar için t-testi, cinsiyet, spor türü ve spor deneyimi değişkenleri ile bağlanma stillerinin duygu düzenleme becerileri ile bilişsel duygu düzenleme stratejilerini yordayıcı gücünü sınamak için hiyerarşik regresyon analizi yapılmıştır.

\section{BULGULAR}

\section{Araştırma Değişkenlerinin Cinsiyete Göre Değerlendirilmesi}

Araştırma değişkenlerinin cinsiyet açısından farklılaşıp farklılaşmadığını tespit amacıyla bağımsız gruplar için t testi uygulanmıştır. Analiz sonucunda istatistiksel açıdan farklılıkların ortaya çıktığ1 değişkenler Tablo 1'de gösterilmiştir.

Tablo 1. Araştırma değişkenlerini cinsiyet açısından karşılaştıran t-testi sonuçları

\begin{tabular}{llcccc}
\hline \multirow{2}{*}{ Değişkenler } & & \multicolumn{2}{c}{ Ort. $\pm \mathbf{S}$} & \multirow{2}{*}{ t } & p \\
\cline { 2 - 4 } & & Erkek & Kadın & & \\
\hline İÖA & Korkulu bağlanma & $14.88 \pm 4.73$ & $15.93 \pm 4.66$ & -2.001 & $\mathbf{0 . 0 4 5}$ \\
\hline BDDS & Diğerlerini suçlama & $11.16 \pm 3.86$ & $10.22 \pm 3.86$ & 2.104 & $\mathbf{0 . 0 2 9}$ \\
\hline
\end{tabular}

İÖA: İlişki Ölçekleri Anketi, BDDS: Bilişsel Duygu Düzenleme Stratejileri Ölçeği 
Tablo 1'de görüldüğü üzere, kadın sporcuların korkulu bağlanma puanları erkek sporcuların korkulu bağlanma puanlarından anlamlı olarak daha yüksek bulunmuştur. Bilişsel Duygu Düzenleme Stratejileri Ölçeği diğerlerini suçlama alt boyut puanının ise erkek sporcularda kadınlardan daha yüksek olduğu tespit edilmiştir.

\section{Araştırma Değişkenlerinin Spor Türüne Göre Değerlendirilmesi}

Araştırma değişkenlerinin spor türü değişkenine göre farklılık gösterip göstermediğini test etmek amacıyla bağımsız gruplar için t testi uygulanmış, sonuçlarda anlamlı farklılıkların oluştuğu araştırma değişkenleri Tablo 2'de gösterilmiştir.

Tablo 2. Araştırma değişkenlerini spor türü açısından karşılaştıran t-testi sonuçları

\begin{tabular}{|c|c|c|c|c|c|}
\hline \multirow{2}{*}{\multicolumn{2}{|c|}{ Değişkenler }} & \multicolumn{2}{|c|}{ Ort. $\pm S$} & \multirow{2}{*}{$\mathbf{t}$} & \multirow{2}{*}{$\mathbf{p}$} \\
\hline & & Bireysel Sporlar & Takım Sporları & & \\
\hline İÖA & Kayıtsız bağlanma & $22.92 \pm 5.03$ & $21.80 \pm 5.08$ & -2.096 & $\mathbf{0 . 0 3 7}$ \\
\hline DDB & Değişimleme & $8.14 \pm 2.26$ & $7.66 \pm 2.20$ & 2.054 & 0.041 \\
\hline \multirow{5}{*}{ BDDS } & Pozitif tekrar odaklanma & $13.27 \pm 3.40$ & $12.29 \pm 3.62$ & 2.655 & 0.008 \\
\hline & Plana tekrar odaklanma & $14.79 \pm 3.24$ & $13.89 \pm 3.35$ & 2.573 & 0.010 \\
\hline & Pozitif yeniden gözden geçirme & $15.26 \pm 3.28$ & $14.31 \pm 3.03$ & 2.839 & 0.005 \\
\hline & Bakış açısına yerleştirmek & $14.34 \pm 3.03$ & $12.94 \pm 3.07$ & 4.352 & 0.000 \\
\hline & Y1kım & $10.42 \pm 3.74$ & $11.32 \pm 4.02$ & -2.184 & $\mathbf{0 . 0 3 0}$ \\
\hline
\end{tabular}

IÖA: İlişki Ölçekleri Anketi, DDB: Duygu Düzenleme Becerileri Ölçeği, BDDS: Bilişsel Duygu Düzenleme Stratejileri Ölçeği

Bireysel performans sporcularının kayıtsız bağlanma, değişimleme, pozitif tekrar odaklanma, plana tekrar odaklanma, pozitif yeniden gözden geçirme ve bakış açısına yerleştirmek puanları takım performans sporcularına göre daha yüksek bulunurken, takım performans sporcularının yıkım puanlarının bireysel performans sporcularından daha yüksek olduğu ortaya çıkmıştır.

\section{Araştırma Değişkenlerinin Deneyime Göre Değerlendirilmesi}

Araştırma değişkenlerinin spor deneyimine göre farklılaşıp farklılaşmadı̆̆ı bağımsız gruplar için t testi ile sınanmış, bulgulanan anlamlı farklılıklar Tablo 3 'te aktarılmıştır.

Tablo 3. Araştırma değişkenlerini spor deneyimi açısından karşılaştıran t-testi sonuçları

\begin{tabular}{|c|c|c|c|c|c|}
\hline \multirow{2}{*}{\multicolumn{2}{|c|}{ Değiş̧kenler }} & \multicolumn{2}{|c|}{ Ort. $\pm S$} & \multirow{2}{*}{$\mathbf{t}$} & \multirow{2}{*}{$\mathbf{p}$} \\
\hline & & 1-9 Yıl & 10 Yll ve üzeri & & \\
\hline \multirow{3}{*}{ İÖA } & Güvenli bağlanma & $20.65 \pm 4.15$ & $21.81 \pm 4.30$ & -2.551 & 0.011 \\
\hline & Saplantılı bağlanma & $16.01 \pm 3.98$ & $14.62 \pm 3.94$ & 3.255 & 0.001 \\
\hline & Kayıtsız bağlanma & $21.90 \pm 5.03$ & $23.03 \pm 5.09$ & -2.096 & 0.037 \\
\hline \multirow{6}{*}{ DDB } & Duygu düzenleme becerileri & $68.92 \pm 14.36$ & $74.40 \pm 16.57$ & -3.333 & 0.001 \\
\hline & Netlik & $7.82 \pm 2.12$ & $8.38 \pm 2.25$ & -2.376 & 0.018 \\
\hline & Anlama & $7.74 \pm 2.36$ & $8.23 \pm 2.19$ & -1.979 & 0.049 \\
\hline & Yüzleşmeye hazırlanma & $7.90 \pm 2.33$ & $8.70 \pm 2.27$ & -3.247 & 0.001 \\
\hline & Öz-destek & $7.89 \pm 2.51$ & $8.99 \pm 2.31$ & -4.212 & 0.000 \\
\hline & Değişimleme & $7.49 \pm 2.18$ & $8.50 \pm 2.20$ & -4.315 & 0.000 \\
\hline \multirow{8}{*}{ BDDS } & Kendini suçlama & $11.76 \pm 3.04$ & $11.10 \pm 2.88$ & 2.062 & 0.040 \\
\hline & Kabul etme & $12.34 \pm 2.85$ & $13.38 \pm 2.87$ & -3.361 & 0.001 \\
\hline & Pozitif tekrar odaklanma & $12.43 \pm 3.53$ & $13.29 \pm 3.51$ & -2.286 & 0.023 \\
\hline & Plana tekrar odaklanma & $13.90 \pm 3.15$ & $14.99 \pm 3.47$ & -3.109 & 0.002 \\
\hline & Pozitif yeniden gözden geçirme & $14.24 \pm 3.00$ & $15.57 \pm 3.30$ & -3.904 & 0.000 \\
\hline & Bakış açısına yerleştirmek & $13.15 \pm 2.98$ & $14.36 \pm 3.20$ & -3.656 & 0.000 \\
\hline & Y1kım & $11.49 \pm 3.86$ & $9.96 \pm 3.92$ & 3.643 & 0.000 \\
\hline & Diğerlerini suçlama & $11.75 \pm 3.73$ & $9.50 \pm 3.71$ & 5.621 & 0.000 \\
\hline
\end{tabular}

IÖA: İlişki Ölçekleri Anketi, DDB: Duygu Düzenleme Becerileri Ölçeği, BDDS: Bilişsel Duygu Düzenleme Stratejileri Ölçeği 
Bulgular; 10 yıl ve üzeri deneyime sahip sporcuların güvenli bağlanma, kayıtsız bağlanma, Duygu Düzenleme Becerileri Ölçeği toplam puanı, netlik, anlama, yüzleşmeye hazırlanma, öz-destek, değişimleme, kabul etme, pozitif tekrar odaklanma, plana tekrar odaklanma, pozitif yeniden gözden geçirme ve bakış açısına yerleştirmek puanlarının 1-9 yıl deneyimli olanlardan daha yükssek olduğunu göstermiştir. 1-9 yıl deneyimli sporcuların ise saplantılı bağlanma, kendini suçlama, yıkım ve diğerlerini suçlama puanları 10 yıl ve üzeri deneyimlilerden daha yüksek bulunmuştur.

\section{Bağlanma Stillerinin Duygu Düzenleme Becerilerini Yordayıcı Etkisi}

Sporcuların bağlanma stillerinin, duygu düzenleme becerilerinin alt ölçeklerini yordamadaki rolünü incelemek amacıyla hiyerarşik regresyon analizi yapılmıştır. Oluşturulan regresyon modeline; cinsiyet, spor türü ve spor deneyimi birinci adımda kontrol değişkeni, bağlanma stilleri ise ikinci adımda yordayıcı değişken olarak eklenmiş, sonuçlar Tablo 4'de sunulmuştur. Birinci adımda modele dahil edilen cinsiyet, spor türü ve spor deneyimi değişkenlerinin özgün katkısının farkındalık, beden duyumları, netlik, anlama, kabul ve tolerans değişkenleri üzerindeki etkisinin anlamsız; yüzleşmeye hazırlanma, öz-destek ve değişimleme değişkenleri üzerindeki özgün katkısının anlamlı olduğu ve bu üç değişkenin yalnızca spor deneyimi ile pozitif yönde anlamlı ilişkili olduğu saptanmıştır (Tablo 4).

Modele ikinci adımda girilen bağlanma stilleri kabul ve tolerans duygu düzenleme becerileri hariç diğer duygu düzenleme becerilerinin anlamlı belirleyicisidir. Bağlanma stillerinin duygu düzenleme becerileri alt boyutlarının belirlenmesine katkısı 0.02 (netlik) ile 0.05 (farkındalık, anlama, yüzleşmeye hazırlanma) arasında değişmektedir. Bağlanma stillerinden güvenli ve kayıtsız bağlanma farkındalık ( $\beta=0.14$ ve $\beta=0.21$ ), beden duyumları $(\beta=0.16$ ve $\beta=0.12)$, anlama $(\beta=0.13$ ve $\beta=0.19$ ) ve öz-destek ( $\beta=0.12$ ve $\beta=0.14$ ) duygu düzenleme becerilerinin pozitif belirleyicisi olarak bulunmuştur. Öte yandan güvenli bağlanma tek başına netlik $(\beta=0.11)$ ve yüzleşmeye hazırlanma $(\beta=0.20)$ duygu düzenleme becerilerinin pozitif belirleyicisi iken, kayıtsız bağlanma değişimleme duygu düzenleme becerisinin $(\beta=0.22)$ pozitif belirleyicisidir (Tablo 4 ).

\section{Bağlanma Stillerinin Bilişsel Duygu Düzenleme Stratejilerini Yordayıcı Etkisi}

Sporcuların bağlanma stillerinin, bilişsel duygu düzenleme stratejilerini yordamadaki rolünü incelemek amacı ile hiyerarşik regresyon analizi yapılmış, sonuçlar Tablo 5'te verilmiştir. Bağlanma stillerinin bilişsel duygu düzenleme stratejilerini yordayıcı etkilerinin saptanması amacı ile gerçekleştirilen hiyerarşik regresyon analizlerinde oluşturulan modellere ilk adımda dahil edilen cinsiyet, spor türü ve spor deneyimi değişkenlerinin özgün katkısının, kendini suçlama ve düşünceye odaklanma değişkenleri üzerindeki etkisi anlamsız; kabul etme, pozitif tekrar odaklanma, plana tekrar odaklanma, pozitif yeniden gözden geçirme, bakış açısına yerleştirmek, yıkım ve diğerlerini suçlama değişkenleri üzerindeki özgün katkısının anlamlı olduğu tespit edilmiştir (Tablo 5).

Modele ikinci adımda giren bağlanma stillerinin özgün katkısının tüm bilişsel duygu düzenleme stratejileri için anlamlı olduğu görülmektedir. Bağlanma stillerinin bilişsel duygu düzenleme stratejilerini açıklamaya katkısı 0.03 (bakış açısına yerleştirme ve pozitif tekrar odaklanma) ile 0.18 (kendini suçlama) arasında değişmektedir. Bağlanma stillerinden korkulu bağlanma tek başına pozitif tekrar odaklanma $(\beta=0.15)$ ve bakış açısına yerleştirmek $(\beta=0.12)$ stratejilerinin pozitif belirleyicisi iken, kayıtsız bağlanma tek başına plana tekrar odaklanma $(\beta=0.25)$ stratejisinin pozitif belirleyicisi olarak bulunmuştur. Saplantılı ve kayıtsız bağlanma stilleri kabul etme $(\beta=0.14$ ve $\beta=0.23$ ) ve düşünceye odaklanma ( $\beta=0.24$ ve $\beta=0.22$ ) stratejileri ile pozitif ilişkili bulunmuştur. 
Tablo 4. Bağlanma stillerinin duygu düzenleme becerilerini yordamasına ilişkin regresyon analizi sonuçları

\begin{tabular}{|c|c|c|c|c|c|c|c|c|c|c|c|c|c|c|c|c|c|c|c|c|c|c|c|c|c|c|c|}
\hline \multirow[b]{2}{*}{ Model 1} & \multicolumn{3}{|c|}{ Farkındalık } & \multicolumn{3}{|c|}{$\begin{array}{c}\text { Beden } \\
\text { duyumları }\end{array}$} & \multicolumn{3}{|c|}{ Netlik } & \multicolumn{3}{|c|}{ Anlama } & \multicolumn{3}{|c|}{ Kabul } & \multicolumn{3}{|c|}{ Tolerans } & \multicolumn{3}{|c|}{$\begin{array}{l}\text { Yüzleşmeye } \\
\text { hazırlanma }\end{array}$} & \multicolumn{3}{|c|}{ Öz-destek } & \multicolumn{3}{|c|}{ Değişimleme } \\
\hline & $\beta$ & $\mathrm{t}$ & $\mathrm{p}$ & $\beta$ & $\mathrm{t}$ & $\mathrm{p}$ & $\beta$ & $\mathrm{t}$ & $\mathrm{p}$ & $\beta$ & $\mathrm{t}$ & $\mathrm{p}$ & $\beta$ & $\mathrm{t}$ & $\mathrm{p}$ & $\beta$ & $\mathrm{t}$ & $\mathrm{p}$ & $\beta$ & $\mathrm{t}$ & $\mathrm{p}$ & $\beta$ & $\mathrm{t}$ & $\mathrm{p}$ & $\beta$ & $\mathrm{t}$ & $\mathrm{p}$ \\
\hline Cinsiyet & -0.01 & -0.09 & 0.93 & 0.01 & 0.24 & 0.81 & -0.06 & -1.10 & 0.27 & -0.00 & -0.03 & 0.97 & -0.04 & -0.70 & 0.48 & -0.05 & -0.88 & 0.38 & 0.02 & 0.30 & 0.76 & 0.00 & -0.01 & 0.99 & 0.03 & 0.56 & 0.58 \\
\hline Spor türü & 0.01 & 0.22 & 0.82 & -0.05 & -0.92 & 0.36 & -0.02 & -0.46 & 0.65 & -0.02 & -.034 & 0.73 & 0.02 & -0.53 & 0.60 & 0.03 & -0.54 & 0.59 & 0.01 & 0.10 & 0.92 & 0.04 & 0.83 & 0.41 & -0.06 & -1.10 & 0.27 \\
\hline \multirow[t]{2}{*}{ Spor deneyimi } & 0.08 & 1.64 & 0.10 & 0.08 & 1.56 & 0.12 & 0.12 & 2.21 & 0.03 & 0.10 & 1.85 & 0.06 & 0.07 & 1.28 & 0.20 & 0.07 & 1.36 & 0.18 & 0.17 & 3.18 & 0.00 & 0.23 & 4.23 & 0.00 & 0.21 & 3.98 & 0.00 \\
\hline & \multicolumn{3}{|c|}{$\begin{array}{l}\mathrm{R}=0.09 \\
\mathrm{R}^{2}=0.02 \\
\text { zt. } \mathrm{R}^{2}=0.01 \\
3,359)=0.91 \\
\mathrm{p}>0.05\end{array}$} & \multicolumn{3}{|c|}{$\begin{array}{c}\mathrm{R}=0.11 ; \\
\mathrm{R}^{2}=0.01 ; \\
\text { Dzt. } \mathrm{R}^{2}=0.00 ; \\
\mathrm{F}(3,359)=1.41 \\
\quad \mathrm{p}>0.05\end{array}$} & \multicolumn{3}{|c|}{$\begin{array}{c}\mathrm{R}=0.14 ; \\
\mathrm{R}^{2}=0.02 ; \\
\text { Dzt. } \mathrm{R}^{2}=0.00 ; \\
\mathrm{F}(3,359)=2.31 \\
\quad \mathrm{p}>0.05\end{array}$} & \multicolumn{3}{|c|}{$\begin{array}{c}\mathrm{R}=0.11 ; \\
\mathrm{R}^{2}=0.01 ; \\
\text { Dzt. } \mathrm{R}^{2}=0.00 ; \\
\mathrm{F}(3,359)=1.34 \\
\quad \mathrm{p}>0.05\end{array}$} & \multicolumn{3}{|c|}{$\begin{array}{c}\mathrm{R}=0.08 ; \\
\mathrm{R}^{2}=0.01 ; \\
\text { Dzt. } \mathrm{R}^{2}=0.00 ; \\
\mathrm{F}(3,359)=0.78 \\
\quad \mathrm{p}>0.05\end{array}$} & \multicolumn{3}{|c|}{$\begin{array}{c}\mathrm{R}=0.09 ; \\
\mathrm{R}^{2}=0.01 ; \\
\text { Dzt. } \mathrm{R}^{2}=0.00 ; \\
\mathrm{F}(3,359)=1.08 \\
\mathrm{p}>0.05\end{array}$} & \multicolumn{3}{|c|}{$\begin{array}{c}\mathrm{R}=0.17 ; \\
\mathrm{R}^{2}=0.03 ; \\
\text { Dzt. } \mathrm{R}^{2}=0.02 ; \\
\mathrm{F}(3,359)=3.53 \\
\mathrm{p}<0.05\end{array}$} & \multicolumn{3}{|c|}{$\begin{array}{c}\mathrm{R}=0.22 ; \\
\mathrm{R}^{2}=0.05 ; \\
\text { Dzt. } \mathrm{R}^{2}=0.04 ; \\
\mathrm{F}(3,359)=6.12 \\
\mathrm{p}<0.001\end{array}$} & \multicolumn{3}{|c|}{$\begin{array}{c}\mathrm{R}=0.23 ; \\
\mathrm{R}^{2}=0.05 ; \\
\text { Dzt. } \mathrm{R}^{2}=0.05 ; \\
\mathrm{F}(3,359)=6.78 \\
\mathrm{p}<0.001\end{array}$} \\
\hline Model 2 & $\beta$ & $\mathrm{t}$ & $\mathrm{p}$ & $\beta$ & $\mathrm{t}$ & $\mathrm{p}$ & $\beta$ & $\mathrm{t}$ & $\mathrm{P}$ & $\beta$ & $\mathrm{t}$ & $\mathrm{p}$ & $\beta$ & $\mathrm{t}$ & $\mathrm{p}$ & $\beta$ & $\mathrm{t}$ & $\mathrm{p}$ & $\beta$ & $\mathrm{t}$ & $\mathrm{p}$ & $\beta$ & $\mathrm{t}$ & $\mathrm{p}$ & $\beta$ & $\mathrm{t}$ & $\mathrm{p}$ \\
\hline Cinsiyet & -0.02 & -0.34 & 0.73 & 0.00 & -0.02 & 0.99 & -0.06 & -1.09 & 0.27 & -0.01 & -0.30 & 0.76 & -0.03 & -0.60 & 0.54 & -0.03 & -.70 & 0.48 & 0.01 & 0.18 & 0.85 & -0.02 & -0.03 & 0.96 & 0.01 & 0.23 & 0.81 \\
\hline Spor türü & 0.02 & 0.37 & 0.71 & -0.06 & -1.05 & 0.30 & -0.02 & -0.40 & 0.68 & -0.01 & -0.28 & 0.77 & 0.03 & 0.65 & 0.51 & -.001 & -0.32 & 0.74 & -0.00 & -0.06 & 0.94 & 0.05 & 0.96 & 0.33 & -0.05 & -0.94 & 0.34 \\
\hline Spor deneyimi & 0.05 & 0.94 & 0.35 & 0.04 & 0.72 & 0.47 & 0.09 & 1.61 & 0.10 & 0.05 & 0.96 & 0.33 & 0.06 & 1.06 & 0.28 & 0.07 & 1.28 & 0.20 & 0.12 & 2.29 & 0.02 & 0.20 & 3.73 & 0.00 & 0.16 & 3.13 & 0.00 \\
\hline Güvenli bağlanma & 0.14 & 2.52 & 0.01 & 0.16 & 3.04 & 0.00 & 0.11 & 1.96 & 0.04 & 0.13 & 2.58 & 0.01 & 0.03 & 0.66 & 0.50 & 0.07 & 1.34 & 0.17 & 0.20 & 3.92 & 0.00 & 0.12 & 2.28 & 0.02 & 0.07 & 1.36 & 0.17 \\
\hline Korkulu bağlanma & 0.03 & 0.43 & 0.67 & 0.06 & 0.90 & 0.37 & -0.04 & -0.61 & 0.53 & 0.01 & 0.17 & 0.86 & -0.06 & -1.02 & 0.30 & -0.05 & -0.82 & 0.41 & 0.05 & 0.86 & 0.38 & -0.01 & -0.24 & 0.80 & -0.01 & -0.27 & 0.78 \\
\hline Saplantılı bağlanma & 0.00 & 0.01 & 0.99 & -0.07 & -1.25 & 0.21 & -0.01 & -0.12 & 0.89 & -0.05 & -0.94 & 0.34 & 0.03 & 0.61 & 0.54 & 0.10 & 1.93 & 0.06 & -0.05 & -1.02 & 0.30 & 0.03 & 0.69 & 0.48 & -0.05 & -1.10 & 0.27 \\
\hline \multirow[t]{2}{*}{ Kayıtsız bağlanma } & 0.21 & 3.43 & 0.00 & 0.12 & 1.97 & 0.04 & 0.11 & 1.81 & 0.07 & 0.19 & 3.25 & 0.00 & 0.07 & 1.20 & 0.23 & 0.08 & 1.45 & 0.14 & 0.10 & 1.67 & 0.09 & 0.14 & 2.45 & 0.01 & 0.22 & 3.72 & 0.00 \\
\hline & \multicolumn{3}{|c|}{$\begin{array}{c}\mathrm{R}=0.27 \\
\mathrm{R}^{2}=0.07 \\
\text { Dzt. } \mathrm{R}^{2}=0.06 \\
\mathrm{~F}(7,359)=4.03\end{array}$} & \multicolumn{3}{|c|}{$\begin{array}{c}\mathrm{R}=0.25 \\
\mathrm{R}^{2}=0.06 ; \\
\text { Dzt. } \mathrm{R}^{2}=0.04 \\
\mathrm{~F}(7,359)=3.33\end{array}$} & \multicolumn{3}{|c|}{$\begin{array}{c}\mathrm{R}=0.21 ; \\
\mathrm{R}^{2}=0.04 ; \\
\mathrm{Dzt} . \mathrm{R}^{2}=0.02 ; \\
\mathrm{F}(7,359)=2.22\end{array}$} & \multicolumn{3}{|c|}{$\begin{array}{c}\mathrm{R}=0.27 \\
\mathrm{R}^{2}=0.07 ; \\
\text { Dzt. } \mathrm{R}^{2}=0.05 ; \\
\mathrm{F}(7,359)=3.95\end{array}$} & \multicolumn{3}{|c|}{$\begin{array}{c}\mathrm{R}=0.12 ; \\
\mathrm{R}^{2}=0.01 ; \\
\text { Dzt. } \mathrm{R}^{2}=0.00 ; \\
\mathrm{F}(7,359)=0.74\end{array}$} & \multicolumn{3}{|c|}{$\begin{array}{c}\mathrm{R}=0.18 ; \\
\mathrm{R}^{2}=0.03 ; \\
\text { Dzt. } \mathrm{R}^{2}=0.01 ; \\
\mathrm{F}(7,359)=1.68\end{array}$} & \multicolumn{3}{|c|}{$\begin{array}{c}\mathrm{R}=0.30 ; \\
\mathrm{R}^{2}=0.09 ; \\
\mathrm{Dzt} . \mathrm{R}^{2}=0.07 ; \\
\mathrm{F}(7,359)=4.85\end{array}$} & $\begin{array}{l}\text { Dzt. } \\
F(7,3\end{array}$ & $\begin{array}{l}R=0.29 \\
2^{2}=0.09 \\
\mathrm{R}^{2}=0 \\
359)= \\
<0.00\end{array}$ & $\begin{array}{l}9 ; \\
.07 \\
4.77 \\
1\end{array}$ & $\begin{array}{l}\text { Dzt. } \\
\text { F(7, }\end{array}$ & $\begin{array}{l}\mathrm{R}=0.33 \\
{ }^{2}=0.11 \\
\mathrm{R}^{2}=0 \\
359)= \\
<0.00\end{array}$ & $\begin{array}{l}; \\
1 ; \\
6.09 \\
6.08 \\
1\end{array}$ \\
\hline
\end{tabular}


Tablo 5. Bağlanma stillerinin bilişsel duygu düzenleme stratejilerini yordamasına ilişkin regresyon analizi sonuçları

\begin{tabular}{|c|c|c|c|c|c|c|c|c|c|c|c|c|c|c|c|c|c|c|c|c|c|c|c|c|c|c|c|}
\hline \multirow[b]{2}{*}{ Model 1} & \multicolumn{3}{|c|}{$\begin{array}{l}\text { Kendini } \\
\text { suçlama }\end{array}$} & \multicolumn{3}{|c|}{ Kabul etme } & \multicolumn{3}{|c|}{$\begin{array}{l}\text { Düşünceye } \\
\text { odaklanma }\end{array}$} & \multicolumn{3}{|c|}{$\begin{array}{c}\text { Pozitif tekrar } \\
\text { odaklanma }\end{array}$} & \multicolumn{3}{|c|}{$\begin{array}{l}\text { Plana tekrar } \\
\text { odaklanma }\end{array}$} & \multicolumn{3}{|c|}{$\begin{array}{c}\text { Pozitif yeniden } \\
\text { gözden geçirme }\end{array}$} & \multicolumn{3}{|c|}{$\begin{array}{l}\text { Bakış açısına } \\
\text { yerleştirmek }\end{array}$} & \multicolumn{3}{|c|}{ Yıkım } & \multicolumn{3}{|c|}{$\begin{array}{l}\text { Diğerlerini } \\
\text { suçlama }\end{array}$} \\
\hline & $\beta$ & $\mathrm{t}$ & $\mathrm{p}$ & $\beta$ & $\mathrm{t}$ & $\mathrm{p}$ & $\beta$ & $\mathrm{t}$ & $\mathrm{p}$ & $\beta$ & $\mathrm{t}$ & $\mathrm{p}$ & $\beta$ & $\mathrm{t}$ & $\mathrm{p}$ & $\beta$ & $\mathrm{t}$ & $\mathrm{p}$ & $\beta$ & $\mathrm{t}$ & $\mathrm{p}$ & $\beta$ & $\mathrm{t}$ & $\mathrm{p}$ & $\beta$ & $\mathrm{t}$ & $\mathrm{p}$ \\
\hline & $-0.00 \mid$ & -0.02 & 0.97 & 0.06 & 1.20 & 0.23 & 0.00 & 0.05 & 0.96 & -0.02 & -0.40 & 0.69 & 0.03 & 0.66 & 0.51 & 0.05 & 0.91 & 0.36 & 0.06 & 1.32 & 0.18 & -0.09 & -1.76 & 0.08 & -0.13 & $-2.51 \mid$ & 0.01 \\
\hline por türü & 0.01 & 0.12 & 0.90 & -0.05 & -1.01 & 0.31 & 0.00 & 0.06 & 0.95 & -0.12 & -2.25 & 0.02 & -0.10 & -1.85 & 0.07 & -0.10 & -1.91 & 0.06 & -0.18 & -3.44 & 0.00 & 0.06 & 1.18 & 0.24 & -0.07 & -1.31 & 0.19 \\
\hline \multirow[t]{2}{*}{ Spor deneyimi } & -0.10 & -1.98 & 0.05 & 0.16 & 3.07 & 0.00 & -0.05 & -0.94 & 0.35 & 0.09 & 1.75 & 0.08 & 0.14 & 2.65 & 0.01 & 0.18 & 3.49 & 0.00 & 0.15 & 2.89 & 0.00 & -0.18 & -3.33 & 0.00 & -0.30 & -5.83 & 0.00 \\
\hline & \multicolumn{3}{|c|}{$\begin{array}{c}\mathrm{R}=0.11 ; \\
\mathrm{R}^{2}=0.01 ; \\
\text { Dzt. } \mathrm{R}^{2}=0.00 ; \\
\mathrm{F}(3,359)=1.42 \\
\quad \mathrm{p}>0.05\end{array}$} & \multicolumn{3}{|c|}{$\begin{array}{c}\mathrm{R}=0.20 \\
\mathrm{R}^{2}=0.04 ; \\
\text { Dzt. } \mathrm{R}^{2}=0.03 ; \\
\mathrm{F}(3,359)=4.74 \\
\mathrm{p}<0.01\end{array}$} & \multicolumn{3}{|c|}{$\begin{array}{c}\mathrm{R}=0.05 ; \\
\mathrm{R}^{2}=0.00 ; \\
\text { Dzt. } \mathrm{R}^{2}=0.00 ; \\
\mathrm{F}(3,359)=0.32 \\
\quad \mathrm{p}>0.05\end{array}$} & \multicolumn{3}{|c|}{$\begin{array}{c}\mathrm{R}=0.17 ; \\
\mathrm{R}^{2}=0.03 ; \\
\text { Dzt. } \mathrm{R}^{2}=0.02 ; \\
\mathrm{F}(3,359)=3.45 \\
\mathrm{p}<0.05\end{array}$} & \multicolumn{3}{|c|}{$\begin{array}{c}\mathrm{R}=0.20 \\
\mathrm{R}^{2}=0.04 \\
\text { Dzt. } \mathrm{R}^{2}=0.03 \\
\mathrm{~F}(3,359)=4.68 \\
\mathrm{p}<0.01\end{array}$} & \multicolumn{3}{|c|}{$\begin{array}{c}\mathrm{R}=0.24 \\
\mathrm{R}^{2}=0.06 \\
\text { Dzt. } \mathrm{R}^{2}=0.05 \\
\mathrm{~F}(3,359)=7.02 \\
\mathrm{p}<0.001\end{array}$} & \multicolumn{3}{|c|}{$\begin{array}{c}\mathrm{R}=0.28 ; \\
\mathrm{R}^{2}=0.08 ; \\
\text { Dzt. } \mathrm{R}^{2}=0.07 ; \\
\mathrm{F}(3,359)=9.74 \\
\mathrm{p}<0.001\end{array}$} & \multicolumn{3}{|c|}{$\begin{array}{c}\mathrm{R}=0.22 ; \\
\mathrm{R}^{2}=0.05 ; \\
\text { Dzt. } \mathrm{R}^{2}=0.04 ; \\
\mathrm{F}(3,359)=6.22 \\
\mathrm{p}<0.001\end{array}$} & \multicolumn{3}{|c|}{$\begin{array}{c}\mathrm{R}=0.32 ; \\
\mathrm{R}^{2}=0.10 ; \\
\text { Dzt. } \mathrm{R}^{2}=0.09 ; \\
\mathrm{F}(3,359)=13.07 \\
\mathrm{p}<0.001\end{array}$} \\
\hline Model 2 & $\beta$ & $\mathrm{t}$ & $\mathrm{p}$ & $\beta$ & $\mathrm{t}$ & $\mathrm{p}$ & $\beta$ & $\mathrm{t}$ & $\mathrm{p}$ & $\beta$ & $\mathrm{t}$ & $\mathrm{p}$ & $\beta$ & $\mathrm{t}$ & $\mathrm{p}$ & $\beta$ & $\mathrm{t}$ & $\mathrm{p}$ & $\beta$ & $\mathrm{t}$ & $\mathrm{p}$ & $\beta$ & $\mathrm{t}$ & $\mathrm{p}$ & $\beta$ & $\mathrm{t}$ & $\mathrm{p}$ \\
\hline & -0.02 & -0.50 & 0.61 & 0.05 & 0.92 & 0.36 & 0.01 & 0.12 & 0.90 & -0.04 & -0.71 & 0.48 & 0.01 & 0.27 & 0.79 & 0.04 & 0.69 & 0.49 & 0.06 & 1.12 & 0.26 & -0.11 & -2.17 & 0.03 & -0.15 & $\mid-3.15$ & 0.00 \\
\hline Spor türü & 0.04 & 0.84 & 0.39 & -0.03 & -0.55 & 0.58 & 0.03 & 0.64 & 0.52 & -0.12 & -2.17 & 0.03 & -0.09 & -1.66 & 0.10 & -0.11 & -2.08 & 0.04 & $-0.17 \mid$ & -3.33 & 0.00 & 0.11 & 2.17 & 0.03 & -0.04 & -0.79 & 0.43 \\
\hline Spor deneyimi & -0.06 & -1.29 & 0.19 & 0.17 & 3.21 & 0.00 & -0.04 & -0.74 & 0.46 & 0.10 & 1.82 & 0.07 & 0.10 & 1.91 & 0.06 & 0.14 & 2.68 & 0.01 & 0.16 & 2.97 & 0.00 & -0.12 & -2.34 & 0.02 & -0.23 & -4.72 & 0.00 \\
\hline Güvenli bağlanma & -0.05 & -1.09 & 0.27 & 0.03 & 0.67 & 0.51 & 0.08 & 1.57 & 0.12 & 0.04 & 0.84 & 0.40 & 0.09 & 1.72 & 0.09 & 0.20 & 3.95 & 0.00 & 0.06 & 1.11 & 0.27 & -0.15 & -2.95 & 0.00 & -0.14 & $-2.94 \mid$ & 0.00 \\
\hline Korkulu bağlanma & 0.16 & 2.92 & 0.00 & 0.08 & 1.31 & 0.19 & -0.01 & -0.20 & 0.84 & 0.15 & 2.39 & 0.02 & 0.02 & 0.40 & 0.69 & 0.10 & 1.66 & 0.10 & 0.12 & 2.05 & 0.04 & 0.07 & 1.18 & 0.24 & 0.21 & 3.86 & 0.00 \\
\hline Saplantılı bağlanma & 0.24 & 4.87 & 0.00 & 0.14 & 2.81 & .001 & 0.24 & 4.55 & 0.00 & 0.06 & 1.07 & 0.28 & -0.02 & -0.43 & 0.67 & -0.04 & -0.70 & 0.49 & 0.08 & 1.58 & 0.12 & 0.28 & 5.72 & 0.00 & 0.26 & 5.48 & 0.00 \\
\hline \multirow[t]{2}{*}{ Kayıtsız bağlanma } & 0.22 & 3.95 & 0.00 & 0.23 & 4.01 & 0.00 & 0.22 & 3.69 & 0.00 & 0.08 & 1.25 & 0.21 & 0.25 & 4.24 & 0.00 & 0.12 & 2.10 & 0.04 & 0.08 & 1.35 & 0.18 & 0.20 & 3.65 & 0.00 & 0.08 & 1.51 & 0.13 \\
\hline & \multicolumn{3}{|c|}{$\begin{array}{c}\mathrm{R}=0.44 ; \\
\mathrm{R}^{2}=0.19 ; \\
\text { Dzt. } \mathrm{R}^{2}=0.18 \\
\mathrm{~F}(7,359)=12.12 \\
\mathrm{p}<0.001\end{array}$} & \multicolumn{3}{|c|}{$\begin{array}{c}\mathrm{R}=0.37 ; \\
\mathrm{R}^{2}=0.14 ; \\
\text { Dzt. } \mathrm{R}^{2}=0.12 ; \\
\mathrm{F}(7,359)=8.13 \\
\mathrm{p}<0.001\end{array}$} & \multicolumn{3}{|c|}{$\begin{array}{c}\mathrm{R}=0.33 ; \\
\mathrm{R}^{2}=0.11 ; \\
\text { Dzt. } \mathrm{R}^{2}=0.09 ; \\
\mathrm{F}(7,359)=6.28 \\
\mathrm{p}<0.001\end{array}$} & \multicolumn{3}{|c|}{$\begin{array}{c}\mathrm{R}=0.27 ; \\
\mathrm{R}^{2}=0.07 ; \\
\text { Dzt. } \mathrm{R}^{2}=0.05 ; \\
\mathrm{F}(7,359)=3.87 \\
\mathrm{p}<0.001\end{array}$} & \multicolumn{3}{|c|}{$\begin{array}{c}\mathrm{R}=0.34 ; \\
\mathrm{R}^{2}=0.11 ; \\
\text { Dzt. } \mathrm{R}^{2}=0.10 ; \\
\mathrm{F}(7,359)=6.48 \\
\mathrm{p}<0.001\end{array}$} & \multicolumn{3}{|c|}{$\begin{array}{c}\mathrm{R}=0.36 ; \\
\mathrm{R}^{2}=0.13 ; \\
\text { Dzt. } \mathrm{R}^{2}=0.11 ; \\
\mathrm{F}(7,359)=7.36 \\
\mathrm{p}<0.001\end{array}$} & \multicolumn{3}{|c|}{$\begin{array}{c}\mathrm{R}=0.34 ; \\
\mathrm{R}^{2}=0.12 ; \\
\text { Dzt. } \mathrm{R}^{2}=0.10 ; \\
\mathrm{F}(7,359)=6.69 \\
\mathrm{p}<0.001\end{array}$} & $\begin{array}{r}\mathrm{R} \\
\text { Dzt. } \\
\mathrm{F}(7,3 \\
\mathrm{p}\end{array}$ & $\begin{array}{l}\mathrm{R}=0.46 \\
\mathrm{R}^{2}=0.2 \\
\mathrm{R}^{2}=\mathrm{C} \\
359)= \\
<0.00\end{array}$ & $\begin{array}{l}1 ; \\
0.19 ; \\
13.10 \\
1\end{array}$ & $\begin{array}{r}\mathrm{R}^{2} \\
\text { Dzt. } \\
\mathrm{F}(7,3 \\
\mathrm{p}\end{array}$ & $\begin{array}{l}{ }^{2}=0.2^{2} \\
\mathrm{R}^{2}=0 \\
359)= \\
<0.00\end{array}$ & $\begin{array}{l}2 ; \\
7 \\
0.26 \\
18.57 \\
01\end{array}$ \\
\hline
\end{tabular}


Korkulu, saplantılı ve kayıtsız bağlanma stilleri ve kendini suçlama stratejileri arasında ise pozitif ilişki vardır. Bu ilişki düzeyi 0.16 (kayıtsız bağlanma) ve 0.24 (saplantı bağlanma) arasında değişmektedir. Bilişsel duygu düzenleme stratejilerinden yıkımın belirleyicileri ise güvenli ( $\beta=$ 0.15), saplantılı $(\beta=0.28)$ ve kayıtsız $(\beta=0.20)$ bağlanma stilleridir. Güvenli bağlanma yıkım stratejilerine benzer şekilde diğerlerini suçlama stratejilerinin de negatif belirleyicisidir $(\beta=-0.14)$. Güvenli bağlanmanın aksine, korkulu $(\beta=0.21)$ ve saplantılı $(\beta=0.26)$ bağlanma stilleri diğerlerini suçlama stratejisi ile pozitif ilişkili bulunmuştur. Güvenli bağlanma öte yandan pozitif yeniden gözden geçirme ile pozitif ilişkilidir $(\beta=0.20)$. Pozitif yeniden gözden geçirme stratejisi ile kayıtsız bağlanma $(\beta=0.12)$ arasında da pozitif ilişki vardır (Tablo 5).

\section{TARTIŞMA, SONUÇ VE ÖNERILER}

$\mathrm{Bu}$ çalışmada, sporcuların bağlanma stillerinin duygu düzenleme becerileri ile bilişsel duygu düzenleme stratejilerini belirlemedeki rolü incelenmiştir. Bu amacın yanında, sporcuların cinsiyet, spor türü ve spor deneyimlerinin bağlanma stilleri, duygu düzenleme becerileri ve bilişsel duygu düzenleme değişkenleri açısından anlamlı şekilde farklılaşıp farklılaşmadığı da analiz edilmiştir.

Cinsiyet değişkeni esas alınarak gerçekleştirilen analizlerde, kadın sporcuların korkulu bağlanma puanları erkek sporcuların puanlarından anlamlı olarak daha yüksek bulunmuştur. Korkulu bağlanma stilini kullananlarda kendiliğin değersiz görüldüğü gibi diğer insanların da olumsuz değerlendirildiği, bireyin sevilmeye layık olmadığı inancını taşıdığı, yakın ilişkilerden kaçındığı, yoğun ilişki sorunları olduğu (Çalışır, 2009), diğerlerini reddedici bulduğu (Sümer ve Güngör, 1999), farklı bağlanma stillerini kullananlara kıyasla daha fazla güce gereksindiği (Aydın, 2002) ve ayrıca artan korkulu bağlanmanın sosyal kaçınma, eleştirilme kaygısı ve sosyal kaygıyı da artırdığı (Karaşar, 2014) bildirilmektedir. Bu ifadelerden hareketle, kadın sporcuların erkek sporculara nazaran değersizlik duygularını daha derin yaşadıkları, kişilerarası ilişkilerde güven hissini daha düşük düzeyde yaşantıladıkları, reddedilme algılarının daha fazla olduğu söylenebilir. $\mathrm{Bu}$ hissiyatın, sporun erkek egemen bir çalışma alanı olmasına, öğrenilmiş toplumsal cinsiyet rollerinin, kadının kendini koruma, kollama, sakınma ve ataerki öğretiye bağlı olarak öne çıkma davranışı geliştirdiğinde toplumsal düzeyde kabul görmeyeceğine ilişkin beliren kaygıya dayalı olarak gelişebileceği düşünülmektedir. Çalışmamızın bu bulgusu Çetin'in (2019) bedensel engelli sporcular, Yüksel ve Öncü'nün (2016) geçmişte kurum bakımında kalmış bireyler, Erözkan'ın (2011) üniversite öğrencileri, Utaş Akhan'ın (2014) hemşirelik öğrencileri ile yaptığı çalışmalarla benzerlik göstermektedir. Farklı olarak, Mülhim vd.'nin (2017) dart sporcularını inceledikleri çalışmada bağlanma stillerinin cinsiyet değişkeni açısından anlamlı bir istatistiksel farklılığa yol açmadığı bulunmuştur. Benzer biçimde, Shi'de (2003), yetişkin bireyler üzerinde yaptığı çalışmada bağlanma stillerinin cinsiyet açısından farklılaşmadığını bildirmiştir.

Araştırma değişkenlerinin cinsiyet açısından sınamalarında ulaşılan bir diğer sonuç, bilişsel duygu düzenleme stratejilerinden diğerlerini suçlama puanlarının erkek sporcularda kadın sporculara göre daha yüksek olduğunu göstermektedir. Buna göre, erkek sporcuların uyumsuz bilişsel duygu düzenleme stratejilerinden diğerlerini suçlamayı kadınlara göre daha fazla sergileme eğiliminde oldukları söylenebilir. Çalışmamızın bu bulgusu, Çelik ve Kocabıyık'ın (2014) genç yetişkinlerin saldırganlık ifade biçimlerini cinsiyet ve bilişsel duygu düzenleme stilleri bağlamında ele aldıkları çalışmaları ile benzerlik göstermektedir. Çelik ve Kocabıyık (2014) ilgili çalışmalarında, genç yetişkin erkeklerin diğerlerini suçlayıcı duygu düzenleme stratejilerini kullanma düzeylerindeki artışın fiziksel saldırganlıklarını artırdığını ortaya koymuşlardır. Zengin (2019) de çalışmasında, 
benzer şekilde erkeklerin diğerlerini suçlama puanlarının kadınlara nazaran daha fazla olduğunu bulmuş, erkeklerin stres veren durumlarla karşılaştıkları hallerde sosyal destek almamaya dönük yönelimlerinin bu sonuca yol açabileceğini bildirmiştir. Nitekim, Davis ve Jowet (2014) sporcularla gerçekleştirdikleri araştırmalarında, güvenli bağlanma stilinin algılanan yüksek sosyal destek ve olumlu duygular ile ilişkili olduğunu, kaygılı ve kaçınmacı bağlanma stillerinin ise algılanan düşük sosyal destek, kişilerarası ilişkilerde çatışma ve olumsuz duygular ile ilişkilendirilebileceğini bildirmişlerdir. Çalışma sonuçlarımızdan farklı olarak, Çetin'in (2019) bedensel engeli olan ve olmayan sporcular özelinde yaptığı araştırmasında bilişsel duygu düzenleme stratejileri içerisinde sadece düşünceye odaklanma alt boyutunun anlamlı biçimde farklılaştığı, kadın sporcuların erkek sporculara kıyasla daha yüksek düşünceye odaklanma puanları aldıkları rapor edilmiştir.

Bireysel ve takım sporcusu olma durumunun duyguları düzenleme becerileri ve bilişsel duygu düzenleme stratejilerini kullanma düzeyleri açısından farklılaşıp farklılaşmadığının saptanmasının amaçlandığg analizlerde; bireysel sporcuların kayıtsız bağlanma, duygu düzenleme becerilerinden değişimleme, bilişsel duygu düzenleme stratejilerinden ise pozitif tekrar odaklanma, plana tekrar odaklanma, pozitif yeniden gözden geçirme ve bakış açısına yerleştirmek alt boyutlarından aldıkları puanlar takım sporcularının puanlarından anlamlı biçimde fazla bulunmuştur. Takım sporcularının ise bilişsel duygu düzenleme stratejilerinden yıkım boyutunda bireysel sporculara kıyasla daha yüksek puanlar aldıkları görülmüştür. Bu sonuçlara göre, bireysel sporcuların takım sporcularına nazaran daha fazla kayıtsız bağlanma davranışı gösterdikleri, değişimleme dışında duygu düzenleme becerilerinin performans sporcularında bireysel ya da takım oyuncusu olmak bakımından bir farklılık yaratmadığı söylenebilir. Narimani ve Basharpoor'un (2009) sporcu ve sporcu olmayan kadınlar örnekleminde yürüttükleri çalışmada ise bulgularımızdan farklı olarak bireysel sporcuların spor yapmayanlara kıyasla güvenli bağlanma puanlarının daha yüksek olduğunu raporladıkları gözlenmektedir. Çalışmamızda, ortaya konan bir diğer sonuçtan, bireysel performans sporcularının bilişsel duygu düzenleme stratejilerini takım sporcularına göre daha yoğun şekilde kullandıkları anlaşılmaktadır. Yapılan analizlerde bireysel sporcuların pozitif tekrar odaklanma, plana tekrar odaklanma, pozitif yeniden gözden geçirme, bakış açısına yerleştirmek de takım sporcularına nazaran daha etkin oldukları, ayrıca olumsuz duygu düzenleme stratejisi olarak yıkımı daha az kullandıkları görülmektedir. Bu bulgular 1şığında, bireysel performans sporcularının takım sporcularından daha fazla olumlu duygu düzenleme stratejilerine yöneldikleri düşünülmektedir. Çetin (2019), araştırmasında engeli olmayan sporcuların bedensel engelli sporculara kıyasla daha yüksek düzeyde korkulu bağlanma gösterdiklerini, bedensel engelli sporcuların ise kabul ve olumlu yeniden odaklanma stratejilerini daha fazla kullandıklarını ortaya koymuş, buradan hareketle, aile içinde güvenli bağlanma stilini geliştirmiş çocukların gerek spora başlama gerekse yetişkinlik süreçlerinde antrenörleri ile benzer bir ilişki geliştirebilmeleri halinde bulundukları ortam ve koşullara uyum süreçlerinin kolaylaşabileceği, antrenöre bağlılık ve branşa bağlılık derecelerinin artabileceği ve motivasyon kaynaklarının içselleştirilebileceği yönünde görüş bildirmiştir.

Araştırma değişkenleri ile sportif geçmişin yıl üzerinden değerlendirilmesine ilişkin sonuçlar, bağlanma stilleri, duygu düzenleme becerileri ve bilişsel duygu düzenleme stratejilerinin istatistiksel açıdan anlamlı biçimde farklılaştığını ortaya koymaktadır. Bulgular; 10 yıl ve üzeri deneyime sahip sporcuların güvenli ve kayıtsız bağlanma puanlarının 1 ila 9 yıl tecrübelilere göre daha yüksek olduğunu, 1 ila 9 yıl spor geçmişi olanların ise 10 yıl ve üzeri deneyimlilerden daha fazla saplantılı bağlanma puanı aldığını göstermektedir. Bir diğer bulgu, artan spor deneyiminin 
sporcuların duygu düzenleme becerilerinde artış kaydettiği yönündedir. Nitekim, 10 yıl ve üzeri sportif geçmişi olan performans sporcularının genel duygu düzenleme becerileri, netlik, anlama, yüzleşmeye hazırlanma, öz-destek ve değişimleme puanlarının 1 ila 9 yıl deneyimlilerden daha yüksek olduğu saptanmıştır. Sportif geçmişin bilişsel duygu düzenleme stratejileri açısından incelenmesinde; 1 ila 9 yıl deneyimli performans sporcularının kendini ve diğerlerini suçlama puanlarının yanı sıra yıkım puanlarının da 10 yıl ve üzeri deneyime sahip sporculardan yüksek olduğu görülmüş, buna ek olarak 10 yıl ve üzeri sportif deneyimin sporcuların kendini kabul, pozitif tekrar odaklanma, plana tekrar odaklanma, pozitif yeniden gözden geçirme ve bakış açısına yerleştirmek puanlarının 1 ila 9 yıl deneyimlilerden daha yüksek olduğu bulunmuştur. Bu bulgular 1şığında, daha az deneyimli sporcuların olumsuz duygu düzenleme stratejilerini daha baskın kullandığı, artan sportif tecrübenin performans sporcularının olumlu bilişsel duygu düzenleme stratejilerini işe koşma yeterliliklerini olumlu yönde etkilediği anlaşılmaktadır. Araştırmamızın bu sonuçlarının, duygu düzenlemenin gelişimsel alt yapı gerektirdiğini öne süren Consedine'in (2011) yetişkin yaşamı boyunca duygu, düzenleme ve öğrenme adlı çalışmasında kaleme aldığı bireylerin yaşları arttıkça, zihinsel ve fiziksel kaynakları farklılık kaydettikçe duygu düzenleme sıklıklarının artış gösterebileceği ve farklı duygu düzenleme stratejilerini öğrenebilecekleri yönündeki savı ile örtüştüğü görülmektedir.

Araştırma bulgularına göre, bağlanma stilleri kabul ve tolerans dişında tüm duygu düzenleme becerilerini yordayıcı nitelik göstermektedir. Yapılan analizlerde; güvenli ve kayıtsız bağlanmanın farkındalığı, beden duyumlarını, anlamayı ve öz-desteği pozitif yönde yordadığı görülmüştür. Analiz sonuçları, netlik ve yüzleşmeye hazırlanmanın ise sadece güvenli bağlanma stili tarafından yordandığını göstermiştir. Mikulincer ve Shaver (2007) da çalışmalarında, güvenli bağlanan bireylerin, istenmeyen duyguların ortaya çıkmasına zemin yaratan içsel veya dışsal uyarıcılarla karşılaşmaları halinde sorun çözme, planlama ve yeniden değerlendirme becerileri gösterdiklerini, olumsuzlukları ise, daha az zarar verici bir bakış açısına yerleştirdiklerini rapor etmektedir. Son olarak, kayıtsız bağlanmanın değişimleme üzerinde pozitif yönlü anlamlı biçimde yordayıcı etkisi olduğu belirlenmiştir. Bir duygu düzenleme becerisi olarak değişimleme, Vatan ve Oruçlular Kahya'ya (2018) göre, bir duygunun niteliği, yoğunluğu ve/veya süresini arzu edilen şekilde değiştirmeyi içermekte, işlevi olmayan duygu düzenleme stratejilerinin kullanımını, kaygı ve kaçınma davranışını azaltıcı, özyeterliği ise artırıcı olmaktadır. Kayıtsız bağlanmanın; bireyin kendilik değerlemesinde kendini değerli ve sevilebilir nitelendirirken diğerlerini olumsuz değerlendirdiği, hayal kırıklığı ve reddedilme kaygılarıyla yakın ilișkilerden kaçındığı, bağımsız ve güçlü görünme çabası içinde olumlu benlik algısını sürdürme yönelimini içerdiği bildirilmektedir (Çalışır, 2009). Terzi ve Cihangir Çankaya'nın (2009) bağlanma stillerinin öznel iyi oluş ve stres ile başa çıkma tutumlarını yordama gücünü inceledikleri çalışmalarında kayıtsız bağlanma stilinin aktif planlama başa çıkma tutumunu anlamlı şekilde yordamakta olduğu rapor edilmektedir. Alanyazında ifade edildiği üzere, aktif planlama; aktif çabayı artırma, eylem planı oluşturma, mevcut ana odaklanma ve sorun çözme becerilerini içermektedir (Aslan, 2007; Terzi ve Cihangir Çankaya, 2009). Aktarılanlardan hareketle, kayıtsız bağlanma stili geliştirmiş sporcuların yüksek düzeyde özsaygı taşıdıkları, güçlü görünme yönelimlerinin bir yansıması olarak diğerlerine duygu ve düşüncelerini açmama tutumunu benimsedikleri, kendi başlarına hareket etmeyi önceliklendiren bir özerklik içinde oldukları düşünülmektedir. Buna ek olarak, performans sporcularının yarışmalarda üstünlüklerini ortaya koyabilmelerini mümkün kılıcı yolları ve stratejileri kurgulamaya dönük bilişsel süreçleri yoğun kullandıkları da dikkate alındığında, sporcularda kayıtsız bağlanmanın farkındalık, beden duyumları, anlama, öz-destek ve 
değişimleme üzerindeki pozitif yönlü anlamlı yordayıcı etkisinin araştırmanın beklenen sonuçlarından biri olduğu söylenebilir.

Duygu düzenleme becerilerinin bağlanma ile ilişkisinin konu edildiği bazı çalışmalarda araştırma bulgularımızla benzerlik ve farklılıklar taşıyan sonuçlar olduğu görülmüştür. Çalışmamızdan farklı olarak, Vatan ve Oruçlular Kahya (2018), duygu düzenleme ile birlikte güvensiz bağlanma stillerini ele aldıkları araştırmalarında, güvensiz bağlanmanın kaygı ve kaçınma boyutları ile duygu düzenleme becerileri arasında negatif yönde istatistiksel açıdan anlamlı bir ilişki olduğunu rapor etmişler, raporlarında güvensiz bağlanma özelliklerinin hem genel duygu düzenleme becerileri hem de duygu düzenlemenin özgül alt boyutları ile negatif yönlü doğrusal ilişki gösterdiğini kaydetmişlerdir. Vatan ve Oruçlular Kahya (2018) ile benzer şekilde Bekaroğlu ve Bozo'nun (2017) ekstrem sporcular örnekleminde ikili bağlanma stili üzerinden duygu düzenlemeyi yorumladığı çalışmalarında yüksek düzeyde kaygılı bağlananların duygularını anlama ve farkında olma konusunda daha çok zorluk yaşamakta oldukları, bu kişilerin olumsuz duyguları yaşarken amaçlarına ulaşmada güçlük çektikleri, kaygılı bağlananların kendilerini zorlayıcı nitelikteki duygulara saplanabildikleri ve verdikleri yoğun uğraş dolayısıyla yoğunlaşma, farklı unsurlara konsantre olma, işlerini tamamlama ve farklı şeyler düşünme konularında da zorlandıkları bildirilmiştir. Aynı çalışmada, kaçıngan bağlanan kişilerin riskli spor aktivitelerine duygularını düzenleme amacıyla katılıyor olabilecekleri vurgulanmıştır. $\mathrm{Bu}$ vurgunun çalışmamızda kayıtsız bağlanma stili gösteren sporcuların dinamikleriyle benzerlik gösterdiği düşünülmektedir. Uğur (2018) ise beden eğitimi dersini alan mesleki ve teknik anadolu lisesi öğrencileri örnekleminde yürüttüğü araştırmasında, çalışmamızdan farklı olarak duygu düzenleme güçlükleri ile demografik özellikler arasındaki ilişkiyi incelemiş, spor yapmanın kendisini olumlu etkilediğini düşünenlerin içsel işlevsel duygu düzenlemelerinin olumsuz etkilendiğini düşünenlere göre daha yüksek olduğunu, sporla uğraşanların daha olumlu sonuçlar gösterdiğini, duygu düzenlemede sporun olumlu etkisinin olduğunu ortaya koymuştur.

Sporcuların bağlanma stillerinin bilişsel duygu düzenleme stratejilerini yordayıcılığını sınamak için yapılan hiyerarşik regresyon analizinde; korkulu, saplantılı ve kayıtsız bağlanmanın kendini suçlamayı; saplantılı ve kayıtsız bağlanmanın kabul etme, düşünceye odaklanma ve yıkımı, korkulu ve saplantılı bağlanmanın diğerlerini suçlamayı pozitif yönde yordadıkları belirlenmiştir. Bunlara ek olarak, korkulu bağlanmanın pozitif tekrar odaklanma ile bakış açısına yerleştirmek; kayıtsız bağlanmanın plana tekrar odaklanma üzerinde pozitif yönlü yordayıcı etkiye sahip oldukları ortaya konmuştur. Ayrıca, güvenli bağlanmanın yıkım ve diğerlerini suçlamayı negatif yönde yordadı̆̆ 1 tespit edilmiştir.

Uyar'ın (2019), bağlanma stilleri ile bilişsel duygu düzenlemenin psikolojik iyi oluşu belirleyici rolünü incelediği çalışmasında; Homan'ın (2016), güvenli bağlanmanın yetişkinlik sürecinde de psikolojik iyi oluşun tüm boyutları ile olumlu ilişki gösterdiği yönündeki savına dayanarak güvenli bağlanmanın yaşam boyu gelişimdeki önemine yaptığı vurgu, çalışmamızın bulgularını destekler nitelikte bulunmuştur. Uyar (2019) çalışmasında, güvenli bağlanma puanlarındaki artışın olumlu bilişsel duygu düzenleme stratejilerinden pozitif tekrar odaklanma, plana tekrar odaklanma ve pozitif yeniden gözden geçirme puanlarında artışa, korkulu ve saplantılı bağlanma puanlarındaki artışın ise olumlu bilişsel duygu düzenleme stratejileri puanlarında azalışa yol açtığını bildirmiştir. Benzer şekilde, Çetin (2019) de çalışmasında, bağlanma stilleri ile bilişsel duygu düzenleme stratejilerini ele almış, ancak çalışmamızdan farklı olarak bu iki değişkenin psikolojik dayanıklılığı yordayıcı rolünü incelemiştir. Çetin (2019) bu çalışmasında, güvenli bağlanma stili ile plan yapmaya yeniden odaklanma, olumlu yeniden değerlendirme, olumlu yeniden odaklanma 
ve olayın değerini azaltma stratejilerinin zihinsel dayanıklılığın önemli yordayıcıları olduğunu bulgulamıştır.

Sonuç olarak, bu çalışmanın bulguları; kadın sporcuların korkulu bağlanma stilini, erkek sporcuların ise diğerlerini suçlama davranışını daha fazla kullandıklarını, sporcuların artan spor deneyimlerinin duygu düzenleme beceri ve olumlu bilişsel duygu stratejilerini artırdığını, bağlanma stillerinin kabul ve tolerans alt boyutları dışında duyguları düzenleme becerileri ile bilişsel duygu düzenleme stratejileri üzerinde yordayıcı role sahip olduğu ortaya koymuştur.

Bulgulardan hareketle, performans sporcularına, mesleğe adım attıkları ilk yıllardan başlayarak kademeli olarak duygu düzenleme beceri ve bilişsel duygu düzenleme stratejilerini etkin bir biçimde işe koşmalarına 1şık tutacak psiko-pedagojik içeriklerle donatılmış eğitim modüllerinin sunulması ve performans sporcusu gelişim programlarının oluşturulmasının katkı sağlayacağı düşünülmüştür.

Kadın performans sporcularının korkulu bağlanma örüntülerinin, erkek performans sporcularının diğerlerini suçlama eğilimlerinin, bireysel sporcuların kayıtsız bağlanma stillerinin, takım sporcularının yıkım davranışlarının sportif performansları üzerindeki yansımalarının incelenerek, sporcuların yeterliliklerinin uygun psikolojik performans danışmanlığı hizmetlerinin sağlanması yoluyla artırılması ve güçlendirilmesinin önemli olduğu ifade edilebilir.

Duygu ve sportif performans ilişkisinin çok boyutlu olarak incelenmesi, alanı kuşatan nicel araştırmalara ek olarak duygu-sportif performans ilişkisine özgü yaklaşım ve kuramların oluşturulmasına destek oluşturacak derinlemesine nitel araştırmalara yönelinmesi, yanı sıra nicel saha çalışmalarının nitel paradigmalarla beslenerek egzersiz ve spor psikolojisi alanının karma yönteme dayalı araştırmalarla zenginleştirilmesi önerilmektedir. 


\section{KAYNAKLAR}

Andrés, M. L., Richaud de Minzi, M. C., Castañeiras, C., Canet-Juric, L. \& Rodríguez-Carvajal, R. (2016). Neuroticism and depression in children: The role of cognitive emotion regulation strategies. The Journal of Genetic Psychology, 177(2), 55-71. https://doi.org/10.1080/00221325.2016.1148659.

Aslan, Ş. (2007). Örgütsel ortamda bireysel stresle başaçıkma tutumlarının araştırılması. Selçuk Üniversitesi Sosyal Bilimler Enstitüsü Dergisi, 18, 67-84. [Erişim adresi: http://dergisosyalbil.selcuk.edu.tr/susbed/article/ view/438].

Aydın, S. (2002). Attachment style and motivational profile. Yayımlanmamış Yüksek Lisans tezi, Orta Doğu Teknik Üniversitesi, Sosyal Bilimler Enstitüsü, Psikoloji Bölümü, Ankara.

Bartholomew, K. \& Horowitz, L. M. (1991). Attachment styles among young adults: A test of a four-category model. Journal of Personality and Social Psychology,61(2), 226-244. https://doi.org/10.1037/00223514.61.2.226.

Bekaroglu, E. \& Bozo, Ö. (2017). The relationship between attachment styles, emotion regulation strategies, and health-promoting behaviors: Extreme sports participants versus non-participants. Journal of Clinical Sport Psychology, 11(2), 89-106. https://doi.org/10.1123/jcsp.2016-0023.

Berking, M. \& Znoj, H. (2008). Entwicklung und validierung eines fragebogens zur standardisierten selbsteinschätzung emotionaler kompetenzen (SEK-27). Zeitschrift Für Psychiatrie, Psychologie und Psychotherapie, 56(2), 141-153. https://doi.org/10.1024/1661-4747.56.2.141.

Bowlby, J. (1983). Attachment: Attachment and loss, Vol. 1. (2nd ed.) New York, NY: Basic Books. ISBN: 0-46500543-8.

Campo, M., Champely, S., Louvet, B., Rosnet, E., Ferrand, C., Pauketat, J. V. \& Mackie, D. M. (2019). Group-based emotions: Evidence for emotion-performance relationships in team sports. Research Quarterly for Exercise and Sport, 90(1), 54-63. https://doi.org/10.1080/02701367.2018.1563274.

Cirhinlioğlu, F. G. (2018). Duygu psikolojisi. Ankara: Nobel. ISBN: 978-605-7928-66-5.

Consedine, N. S. (2011). Emotion, regulation, and learning across the adult lifespan: Implications from developmental functionalism. In C. Hoare (Ed.), The Oxford Handbook of Reciprocal Adult Development Learning (132154). New York, NY: Oxford University Press. ISBN: 978-0-19-973630-0.

Costa, S., Santi, G., di Fronso, S., Montesano, C., Di Gruttola, F., Ciofi, E. G., Morgili, L. \& Bertollo, M. (2020). Athletes and adversities: athletic identity and emotional regulation in time of COVID-19. Sport Sciences for Health, 1-10. https://doi.org/10.1007/s11332-020-00677-9.

Çalışır, M. (2009). Yetişkin bağlanma kuramı ve duygulanım düzenleme stratejilerinin depresyonla ilişkisi. Psikiyatride Güncel Yaklaşımlar, 1(3), 240-255. [Erişim adresi: http://www.cappsy.org/archives /vol1/cap_1_18.pdf].

Çelik, H. ve Kocabıyık, O. O. (2014). Genç yetişkinlerin saldırganlık ifade biçimlerinin cinsiyet ve bilişsel duygu düzenleme tarzları bağlamında incelenmesi. Trakya Üniversitesi Eğitim Fakültesi Dergisi, 4(1), 139-155. [Erişim adresi: https://dergipark.org.tr/tr/download/article-file/200334].

Çetin, S. (2019). Zihinsel dayanıklılık, bağlanma stilleri ve bilişsel duygu düzenleme: Bedensel engeli olan ve olmayan sporcular üzerine bir çalışma. Yayınlanmamış Doktora tezi, Ege Üniversitesi, Sağlık Bilimleri Enstitüsü, Sporda Psiko-Sosyal Alanlar Anabilim Dalı, İzmir.

Davis, L. \& Jowett, S. (2014). Coach-athlete attachment and the quality of the coach-athlete relationship: implications for athlete's well-being. Journal of Sports Sciences, 32(15), 1454-1464. https://doi.org/10.1080/02640414. 2014.898183 .

Elibol, Ş. ve Sevi Tok, E. S. (2019). Bağlanma stilleri, duygu düzenleme, reddedilme duyarlılığı, yakınlık korkusu ve kendini saklamanın kırılgan narsisizm ile ilişkisi. Ayna Klinik Psikoloji Dergisi, 6(2), 127-148. https://doi.org/10.31682/ayna.515625. 
Öner, Ç. ve Aş̧̧ı, F. H. (2020). Sporcularda bağlanma stillerinin duyguları düzenleme becerileri ve bilişsel duygu düzenleme stratejilerini belirlemedeki rolünün incelenmesi. Spor Bilimleri Araştırmaları Dergisi, 5(2), 202-219.

Erözkan, A. (2011). Üniversite öğrencilerinin bağlanma stilleri ve karar stratejileri. Uluslararası Avrasya Sosyal Bilimler Dergisi, 2(3), 60-74. [Erişim adresi: http://www.ijoess.com/DergiTamDetay.aspx?ID=49\& Detay= Ozet].

Freud, A. (2018). The ego and the mechanisms of defence. Oxon: Routledge. ISBN: 978-1855750388.

Frijda, N. H. (1986). The emotions. New York, NY: Cambridge University Press. ISBN: 0-521-31600-6.

Garnefski, N. \& Kraaij, V. (2007). The cognitive emotion regulation questionnaire psychometric features and prospective relationships with depression and anxiety in adults. European Journal of Psychological Assessment, 23(3), 141-149. https://doi.org/10.1027/1015-5759.23.3.141.

Garnefski, N. \& Kraaij, V. (2006). Relationships between cognitive emotion regulation strategies and depressive symptoms: A comparative study of five specific samples. Personality and Individual Differences, 40(8), 1659-1669. https://doi.org/10.1016/j.paid.2005.12.009.

Garnefski, N., Kommer, T. V. D., Kraaij, V., Teerds, J., Legers-tee, J. \& Onstein, E. (2002). The relationship between cognitive emotion regulation strategies and emotional problems: Comparison between a clinical and a nonclinical Sample. European Journal of Personality, 16, 403-420. https://doi.org/10.1002/per.458.

Garnefski, N., Kraaij, V. \& Spinhoven, P. (2001). Negative life events, cognitive emotion regulation and emotional problems. Personality and Individual Differences, 30(8), 1311-1327. https://doi.org/10.1016/S0191-8869 (00)00113-6.

Gratz, K. L. \& Roemer, L. (2004). Multidimensional assessment of emotion regulation and dysregulation: Development, factor structure, and initial validation of the difficulties in emotion regulation scale. Journal of Psychopathology and Behavioral Assessment, 26(1), 41-54. https://doi.org/10.1023/B:JOBA.00000074 55.08539 .94

Gross, J. J. (2014). Emotion regulation: Conceptual and empirical foundations. In J. J. Gross (Ed.), Handbook of Emotion Regulation (3-22). New York, NY: Guilford Press. ISBN: 978-1-4625-0350-6.

Griffin, D. W. \& Bartholomew, K. (1994). The metaphysics of measurement: The case of adult attachment. In K. Bartholomew \& D. Perlman (Eds.), Advances in Personal Relationships, Vol. 5. Attachment Processes in Adulthood (17-52). London: Jessica Kingsley Publishers. ISBN: 1-85302-172-5.

Hazan, C. \& Shaver, P. R. (1994). Attachment as an organizational framework for research on close relationships. Psychological Inquiry, 5(1), 1-22. https://doi.org/10.1207/s15327965pli0501_1.

Hill, A. P. \& Davis, P. A. (2014). Perfectionism and emotion regulation in coaches: A test of the $2 \times 2$ model of dispositional perfectionism. Motivation and Emotion, 38(5), 715-726. https://doi.org/10.1007/s11031-0149404-7.

Homan, K. J. (2016). Self-compassion and psychological well-being in older adults. Journal of Adult Development, 16(23), 111-119. https://doi.org/10.1007/s10804-016-9227-8.

Josefsson, T., Ivarsson, A., Lindwall, M., Gustafsson, H., Stenling, A., Böröy, J., Mattsson, E., Carnebratt, J. Sevholt, S. \& Falkevik, E. (2017). Mindfulness mechanisms in sports: mediating effects of rumination and emotion regulation on sport-specific coping. Mindfulness, 8(5), 1354-1363. https://doi.org/10.1007/s12671-0170711-4.

Karasar, N. (2020). Bilimsel araştırma yöntemi: Kavramlar ilkeler teknikler. Ankara: Nobel. ISBN: 978-605-5426$58-3$.

Karaşar, B. (2014). Öğretmen adaylarının bağlanma stilleri ve sosyal kaygı düzeyleri arasındaki ilişki. Amasya Üniversitesi Ĕ̆itim Fakültesi Dergisi, 3(1), 27-49. ISSN: 2146-7811. [Erişim adresi: https://dergipark.org.tr /tr/download/ article-file/19620].

Kavussanu, M. (2008). Moral behaviour in sport: A critical review of the literature. International Review of Sport and Exercise Psychology, 1(2), 124-138. https://doi.org/10.1080/17509840802277417.

Kraaij, V., Garnefski N. \& Vlietstra A. (2008). Cognitive coping and depressive symptoms in definitive infertility: A prospective study. Journal of Psychosomatic Obstetrics \& Gynecology, 29(1), 9-16. https://doi.org/10.1080 /01674820701505889. 
Lane, A. M., Beedie, C. J., Jones, M. V., Uphill, M., \& Devonport, T. J. (2012). The BASES expert statement on emotion regulation in sport. Journal of Sports Sciences, 30(11), 1189-1195. https://doi.org/10.1080 /02640414.2012.693621.

Lane, A. M., Beedie, C. J., Devonport, T. J. \& Stanley, D. M. (2011). Instrumental emotion regulation in sport: Relationships between beliefs about emotion and emotion regulation strategies used by athletes. Scandinavian Journal of Medicine \& Science in Sports, 21(6), e445-e451. https://doi.org/10.1111/j.16000838.2011.01364.x

Lazarus, R. S. (1966). Psychological stress and the coping process. New York, NY: McGraw-Hill.

Liu, C., Marchewka, J. T., Lu, J. \& Yu, C. S. (2005). Beyond concern-a privacy-trust-behavioral intention model of electronic commerce. Information \& Management, 42(2), 289-304. https://doi.org/10.1016/j.im.2004. 01.003 .

Main, M., Kaplan, N. \& Cassidy, J. (1985). Security in infancy, childhood, and adulthood: A move to the level of representation. Monographs of the Society for Research in Child Development, 50(1/2): 66-104. https:// doi.org/10.2307/3333827.

Mikulincer, M. \& Shaver, P. R. (2007). Attachment in adulthood: Structure, dynamics, and change. New York, NY: Guilford Press. ISBN: 1593854579.

Molina, V. M., Oriol, X. \& Mendoza, M. C. (2018). Emotional regulation and physical recovery in young athletes of individual and collective sport modalities. RICYDE: Revista Internacional de Ciencias del Deporte, 14(53), 191-204. https://doi.org/10.5232/ricyde2018.05301.

Mülhim, M. A., Mülhim, Z., Ünlü, Y. ve Solakumur, A. (2017). Dart sporcularının erişkin bağlanma biçimleri ile atılganlık düzeyleri arasındaki ilişkinin incelenmesi. International Journal of Cultural and Social Studies (IntJCSS), 3(SI), 61-72. [Erişim adresi: https://dergipark.org.tr/en/download/article-file/388142].

Narimani, M. \& Basharpoor, S. (2009). Comparison of attachment styles and emotional intelligence between athlete women (collective and individual sports) and non-athlete women. Research Journal of Biological Sciences, 4(2), 216-221. [Erişim adresi: http://docsdrive.com/pdfs/medwelljournals/rjbsci/2009/216-221. Pdf].

Onat, O. ve Otrar, M. (2010). Bilişsel duygu düzenleme ölçeğinin Türkçeye uyarlanması: Geçerlik ve güvenirlik çalışmaları. Marmara Üniversitesi Atatürk Ĕgitim Fakültesi Eğitim Bilimleri Dergisi, 31(31), 123-143. [Erişim adresi: https://dergipark.org.tr/tr/download/article-file/1656].

Öpöz, T. Y. (2017). Spor veya sanatla uğraşan ergenlerin duygu düzenleme becerileri, sosyal kaygl ve öfke düzeyleri arasındaki ilişki. Yayımlanmamış Doktora tezi, Ankara Üniversitesi Sosyal Bilimler Enstitüsü, Psikoloji Anabilim Dalı, Ankara.

Schroevers, M., Kraaij, V. \& Garnefski, N. (2007). Goal disturbance, cognitive coping strategies, and psychological adjustment to different types of stressful life event. Personality and Individual Differences, 43(2), 413-423. https://doi.org/10.1016/j.paid.2006.12.009.

Shi, L. (2003). The association between adult attachment styles and conflict resolution in romantic relationships. The American Journal of Family Therapy, 31(3), 143-157. https://doi.org/10.1080/01926180301120.

Shields, D. L. \& Bredemeier, B. L. (2007). Advances in sport morality research. In G. Tenenbaum \& R. C. Eklund (Eds.), Handbook of Sport Psychology (662-684). USA: John Wiley \& Sons Inc. ISBN-13: 9780471738114.

Sümer, N. ve Güngör, D. (1999). Yetişkin bağlanma stilleri ölçeklerinin Türk örneklemi üzerinde psikometrik değerlendirmesi ve kültürlerarası bir karşılaştırma. Türk Psikoloji Dergisi, 14(43), 71-106. [Erişim adresi: http://www.nebisumer.com/wp-content/uploads/2016/01/Sumer-Gungor_baglanma_TPD1999_14_71106.pdf].

Şahin, T. ve Güçlü, M. (2018). Sporcularda psikolojik dayanıklılığın duygu düzenleme becerilerine etkisi: Türkiye korumalı futbol 1. ligi oyuncuları örneği. SPORMETRE Beden Eğitimi ve Spor Bilimleri Dergisi, 16(3), 204-216. https://doi.org/10.1501/Sporm_0000000388. 
Tamminen, K. A. \& Gaudreau, P. (2014). Coping, social support, and emotion regulation in teams In M. R. Beauchamp \& M. A. Eys (Eds.). Group Dynamics in Exercise and Sport Psychology (222-239). Oxon: Routledge. ISBN-13: 978-0-415-83577-0.

Tamminen, K. A. \& Crocker, P. R. (2013). "I control my own emotions for the sake of the team": Emotional selfregulation and interpersonal emotion regulation among female high-performance curlers. Psychology of Sport and Exercise, 14(5), 737-747. https://doi.org/10.1016/j.psychsport.2013.05.002.

Terzi, Ş. ve Çankaya, Z. C. (2016). Bağlanma stillerinin öznel iyi olmayı ve stresle başa çıkma tutumlarını yordama gücü. Türk Psikolojik Danışma ve Rehberlik Dergisi, 4(31): 1-11. [Erişim adresi: https://dergipark.org.tr /tr/download/ article-file/200017].

Uğur, C. (2018). Beden eğitimi dersi alan mesleki ve teknik anadolu lisesi öğrencilerinin duygu düzenleme güçlükleri ile sosyo-demografik özellikleri arasındaki ilişkinin incelenmesi: Antakya örneği. Yayımlanmamış Yüksek Lisans tezi, Çă̆ Üniversitesi, Sosyal Bilimler Enstitüsü, Psikoloji Anabilim Dalı, Mersin.

Utaş Akhan, L. (2014). Hemşirelik öğrencilerinin bağlanma stillerinin belirlenmesi. Yükseköğretim ve Bilim Dergisi, 4(3), 191-196. https://doi.org/10.5961/jhes.2014.103.

Uyar, M. (2019). Beliren yetişkinlik dönemindeki bireylerin psikolojik iyi oluş düzeylerini yordamada bağlanma tarzlart ve bilişsel duygu düzenlemenin rolünün incelenmesi. Yayımlanmamış Yüksek Lisans tezi, Maltepe Üniversitesi, Sosyal Bilimler Enstitüsü, Psikoloji Anabilim Dalı, İstanbul.

Wagstaff, C. R. (2014). Emotion regulation and sport performance. Journal of Sport and Exercise Psychology, 36(4), 401-412. https://doi.org/10.1123/jsep.2013-0257.

Vatan, S. ve Oruçlular Kahya, Y. (2018). Duygu düzenleme becerileri ölçeğinin Türkçeye uyarlanması: Geçerlilik ve güvenilirlik çalışması. Anatolian Journal of Psychiatry, 19(2), 192-201. https://doi.org/10.5455/apd.260322.

Yüksel, Z. ve Öncü, B. (2016). Geçmişte kurum bakımında kalmış bireylerin kurum bakımı deneyimlerine ilişkin özellikleri ve bağlanma biçimlerinin incelenmesi. Journal of Society \& Social Work, 27(2), 63-77. [Erişim adresi: https://dergipark.org.tr/tr/download/article-file/515084].

Zengin, M. (2019). Üniversite ögrrencilerinde mükemmeliyetçilik, bilişsel duygu düzenleme stratejileri ve kaygl arasındaki ilişkiler. Yayımlanmamış Yüksek Lisans tezi, Maltepe Üniversitesi, Sosyal Bilimler Enstitüsü, Psikoloji Anabilim Dalı, İstanbul.

Bu eser Creative Commons Atıf-GayriTicari 4.0 Uluslararası Lisansı ile lisanslanmıştır. 